\title{
Carbon isotope ratioss of coccolith- associated polysaccharides of Emiliania huxleyi as a function of growth rate and CO2 concentration
}

Article

Accepted Version

Creative Commons: Attribution-Noncommercial-No Derivative Works 4.0

Wilkes, E. B., Lee, R. B. Y., McClelland, H. L.O., Rickaby, R. E.M. and Pearson, A. (2018) Carbon isotope ratioss of coccolith-associated polysaccharides of Emiliania huxleyi as a function of growth rate and $\mathrm{CO} 2$ concentration. Organic Geochemistry, 119. pp. 1-10. ISSN 0146-6380 doi:

https://doi.org/10.1016/j.orggeochem.2018.02.006 Available at https://centaur.reading.ac.uk/75640/

It is advisable to refer to the publisher's version if you intend to cite from the work. See Guidance on citing.

Published version at: https://www.sciencedirect.com/science/article/pii/S0146638018300251?via\%3Dihub To link to this article DOI: http://dx.doi.org/10.1016/j.orggeochem.2018.02.006

Publisher: Elsevier

All outputs in CentAUR are protected by Intellectual Property Rights law, including copyright law. Copyright and IPR is retained by the creators or other copyright holders. Terms and conditions for use of this material are defined in the End User Agreement. 


\section{www.reading.ac.uk/centaur}

\section{CentAUR}

Central Archive at the University of Reading

Reading's research outputs online 


\section{Accepted Manuscript}

Carbon isotope ratios of coccolith-associated polysaccharides of Emiliania huxleyi as a function of growth rate and $\mathrm{CO}_{2}$ concentration

Elise B. Wilkes, Renee B.Y. Lee, Harry L.O. McClelland, Rosalind E.M. Rickaby, Ann Pearson

PII: S0146-6380(18)30025-1

DOI: https://doi.org/10.1016/j.orggeochem.2018.02.006

Reference: OG 3681

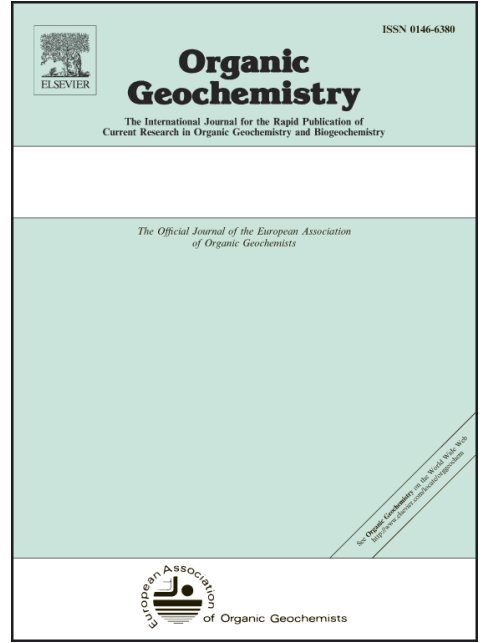

To appear in:

Organic Geochemistry

Received Date: $\quad 16$ November 2017

Revised Date: $\quad 30$ January 2018

Accepted Date: $\quad 8$ February 2018

Please cite this article as: Wilkes, E.B., Lee, R.B.Y., McClelland, H.L.O., Rickaby, R.E.M., Pearson, A., Carbon isotope ratios of coccolith-associated polysaccharides of Emiliania huxleyi as a function of growth rate and $\mathrm{CO}_{2}$ concentration, Organic Geochemistry (2018), doi: https://doi.org/10.1016/j.orggeochem.2018.02.006

This is a PDF file of an unedited manuscript that has been accepted for publication. As a service to our customers we are providing this early version of the manuscript. The manuscript will undergo copyediting, typesetting, and review of the resulting proof before it is published in its final form. Please note that during the production process errors may be discovered which could affect the content, and all legal disclaimers that apply to the journal pertain. 
Carbon isotope ratios of coccolith-associated polysaccharides of Emiliania huxleyi as a function of growth rate and $\mathrm{CO}_{2}$ concentration

Elise B. Wilkes ${ }^{\text {a* }}$, Renee B.Y. Lee ${ }^{\text {b,c }}$, Harry L.O. McClelland ${ }^{\text {b,d }}$, Rosalind E.M.

Rickaby ${ }^{\mathrm{b}}$, Ann Pearson ${ }^{\mathrm{a}}$

${ }^{a}$ Department of Earth and Planetary Sciences, Harvard University, Cambridge, MA, USA

${ }^{\mathrm{b}}$ Department of Earth Sciences, University of Oxford, Oxford, UK

${ }^{\mathrm{c}}$ School of Biological Sciences, University of Reading, Reading, UK

${ }^{\mathrm{d}}$ Department of Earth and Planetary Sciences, Washington University in St. Louis, MO, USA

*Corresponding author: elisewilkes@fas.harvard.edu 


\section{ABSTRACT}

The calcite plates, or coccoliths, of haptophyte algae including Emiliania huxleyi are formed in intracellular vesicles in association with water-soluble acidic polysaccharides. These coccolith-associated polysaccharides (CAPs) are involved in regulating coccolith formation and have been recovered from sediment samples dating back to $180 \mathrm{Ma}$. Paired measurements of the carbon isotopic compositions of CAPs and coccolith calcite have been proposed as a novel paleo- $p \mathrm{CO}_{2}$ barometer, but additional proxy validation and development are still required. Here we present culture results quantifying carbon isotopic offsets between CAPs and other cellular components: bulk organic biomass, alkenones, and calcite. E. huxleyi was grown in nitrate-limited chemostat experiments at growth rates $(\mu)$ of $0.20-0.62 / \mathrm{d}$ and carbon dioxide concentrations of $10.7-17.6 \mu \mathrm{mol} / \mathrm{kg}$. We find that CAPs are isotopically enriched by $4.5 \%$ to $10.1 \%$ relative to bulk organic carbon, exhibiting smaller isotopic offsets at faster growth rates and lower $\mathrm{CO}_{2}$ concentrations. This variability suggests that CAPs record a complementary signature of past growth conditions with different sensitivity than alkenones or coccolith calcite. By measuring the isotopic compositions of all three molecules and minerals of selfconsistent origin, the ratio $\mu /\left[\mathrm{CO}_{2(\mathrm{aq})}\right]$ may be reconstructed with fewer assumptions than current approaches.

Keywords: polysaccharide, coccolith, alkenone, isotope fractionation, chemostat, climate proxy, E. huxleyi, paleobarometry 


\section{Introduction}

Emiliania huxleyi is a cosmopolitan, bloom-forming marine algal species that uses dissolved inorganic carbon (DIC) for calcification and photosynthesis (Westbroek, 1993). It is the dominant coccolithophore in modern oceans, capable of producing calcifying plates ("coccoliths") that interlock around the cell (De Vargas et al., 2007; Henriksen and Stipp, 2009). The stable carbon and oxygen isotopic compositions of fossilized coccoliths have been used to reconstruct paleoclimatic and evolutionary events (Stoll, 2005; Rickaby et al., 2007; Hermoso et al., 2009; Bolton and Stoll, 2013). E. huxleyi and its ancestors within the family Noëlaerhabdaceae also synthesize long-chain unsaturated ketones called alkenones (Volkman et al., 1980) that are preserved in the geologic record and used as paleotemperature and paleobarometry $\left(p \mathrm{CO}_{2}\right)$ proxies (e.g.,

Marchal et al., 2002; Pagani et al., 2005; Zhang et al., 2013; Brassell, 2014). Although E. huxleyi only became dominant in the fossil record around $70 \mathrm{ka}$, alkenones first appear in Cretaceous sediments, and fossil coccoliths have been dated to the Late Triassic (Thierstein et al., 1977; Farrimond et al., 1986; Bown et al., 1987).

Coccolith precipitation occurs intracellularly in vesicles that maintain a controlled chemical composition (Henriksen and Stipp, 2009). Coccolithogenesis begins with the formation of precursor organic templates that provide a framework of binding sites for crystal nucleation and growth (Young et al., 2003). The calcite crystals grow to form complex units, with mineral expression regulated by acidic polysaccharides (Marsh, 2003). Completed coccoliths and coccolith-associated polysaccharides (CAPs) trapped within ultimately are expelled to the outside of the cell. E. huxleyi contains one type of $\mathrm{CAP}$, consisting of a polymeric mannose backbone with sidechains of galacturonic acid 
and ester-bound sulfate groups (De Jong et al., 1976; Fichtinger-Schepman et al., 1981; Kok et al., 1986). Another coccolithophore species, Pleurochrysis carterae, contains three types of CAPs, with both galacturonic and glucuronic moieties (Marsh et al., 1994, 2002). CAPs interact with the carbonate chemistry of the coccolith vesicle through the carboxyl groups of the uronic acid residues, which can shed protons to preferentially bind calcium cations (Borman et al., 1982).

CAPs are increasingly being used to study the interplay between the ambient environment and the carbonate chemistry of intracellular carbon pools (Henriksen and Stipp, 2009; Lee et al., 2016; Rickaby et al., 2016). Lee et al. (2016) extracted intact CAPs from both modern cultures and fossil coccoliths dating back to $180 \mathrm{Ma}$. The uronic acid contents of these extracts correlated with the predicted internal saturation state of the coccolith vesicle in modern cultures and approximately tracked Phanerozoic $p \mathrm{CO}_{2}$ reconstructions obtained from other paleo-proxies (Lee et al., 2016).

The stable carbon isotopic composition of CAPs $\left(\delta^{13} \mathrm{C}_{\mathrm{CAP}}\right)$ may provide further complementary information. $\delta^{13} \mathrm{C}_{\mathrm{CAP}}$ values, measured in conjunction with coccolith calcite $\delta^{13} \mathrm{C}$ values, have been proposed as a novel paleobarometer for ancient $p \mathrm{CO}_{2}$ (Hermoso, 2014; McClelland et al., 2017). Such application assumes that $\delta^{13} \mathrm{C}_{\mathrm{CAP}}$ values predictably track $\delta^{13} \mathrm{C}_{\text {biomass }}$ values and can be used to calculate the isotope fractionation accompanying photosynthesis ( $\varepsilon_{\mathrm{P}}$ values; Freeman and Hayes, 1992). Preliminary work shows that $\delta^{13} \mathrm{C}_{\mathrm{CAP}}$ values are measurable (R.B.Y. Lee, unpublished; McClelland et al., 2015), but no paired measurements of $\delta^{13} \mathrm{C}_{\mathrm{CAP}}$ values and bulk organic carbon have been reported. In this study we measure the $\delta^{13} \mathrm{C}$ values of CAPs, bulk cellular organic carbon, calcite, and alkenones of E. huxleyi grown in nitrate-limited chemostat cultures. Results 
are analyzed as a function of growth rate and $\mathrm{CO}_{2}$ availability, with all other culture conditions held constant.

\section{Materials and methods}

\subsection{Chemostat culture methods}

A coccolith-bearing strain of E. huxleyi (CCMP3266, isolated from the South Pacific in 1998) was grown in a nitrate-limited chemostat at a constant temperature of 18 ${ }^{\circ} \mathrm{C}$. Experimental conditions were selected to mimic the cultures of Bidigare et al. (1997) and employed the chemostat system described in Wilkes et al. (2017). Cool-white fluorescent light was supplied continuously with a saturating photon flux density of $\sim 150$ $\mu \mathrm{mol}$ photons $/ \mathrm{m}^{2} \mathrm{~s}(400-700 \mathrm{~nm}$ radiation). The vessel was stirred at $50 \mathrm{rpm}$. The growth medium consisted of $0.2 \mu \mathrm{m}$ filtered and autoclaved Gulf of Maine natural seawater enriched with metals and vitamins according to L1 medium (Guillard and Hargraves, 1993). Initial nitrate and phosphate concentrations were adjusted to approximately 100 $\mu \mathrm{M}$ and $36 \mu \mathrm{M}$, respectively. Four different growth rates $(\mu ; 0.20-0.62 / \mathrm{d}$; Table 1$)$ were achieved by adjusting the dilution rate.

Cell densities were monitored daily by $\mathrm{OD}_{600}$ and by cell counts using a hemocytometer counting chamber and a light microscope, yielding reasonable correlation between approaches $\left(r^{2}=0.72\right.$, all experiments $)$. Residual nitrate and phosphate concentrations were determined spectrophotometrically on $0.22 \mu \mathrm{m}$ filtered and refrigerated samples using the resorcinol (Zhang and Fischer, 2006) and mixed molybdate (Strickland and Parsons, 1968) methods, respectively. Daily sample removal never exceeded $4 \%$ of the culture volume to minimize perturbations to steady state 
conditions. Cell size measurements were not performed in this study. By analogy with other nitrate-limited chemostat studies of E. huxleyi over relevant $\mathrm{CO}_{2}$ ranges, we assume that cell diameter changed minimally between experiments and is not a primary control on our isotopic results (Popp et al., 1998; Müller et al., 2012).

\subsection{Carbonate system chemistry}

Four $\mathrm{CO}_{2}$ concentrations from 10.7 to $17.6 \mu \mathrm{mol} / \mathrm{kg}$ (Table 1 ) were maintained by bubbling with mixtures of tank $\mathrm{CO}_{2}\left(\delta^{13} \mathrm{C}_{\mathrm{CO} 2}=-38.58 \pm 0.03 \%\right.$ ) and $4: 1 \mathrm{~N}_{2}: \mathrm{O}_{2} \cdot \mathrm{pH}$ was monitored continuously using an in-process $\mathrm{pH}$ probe (EasyFerm Plus, Hamilton) and ranged from 8.0 to 8.2 across all four experiments. Total dissolved inorganic carbon (DIC) and alkalinity samples were taken daily during the steady state phase of each experiment (final 3-6 days). Samples for DIC were collected without headspace, poisoned with $0.2 \mathrm{w} / \mathrm{w} \%$ sodium azide, and stored in darkness at $4{ }^{\circ} \mathrm{C}$. DIC was converted to $\mathrm{CO}_{2}$ by acidification with $\mathrm{H}_{3} \mathrm{PO}_{4}$, purified on a vacuum line, and quantified manometrically, yielding a range of $1740-1880 \mu \mathrm{mol} / \mathrm{kg}$. Total alkalinity was determined by Gran titration with $0.01 \mathrm{~N} \mathrm{HCl}$ solution prepared in a $0.7 \mathrm{M} \mathrm{NaCl}$ background (Gran, 1952; Dickson et al., 2007), using certified reference materials supplied by A.G. Dickson (Scripps Institution of Oceanography) to monitor precision. The carbonate system was calculated from DIC, $\mathrm{pH}$, phosphate, temperature, and salinity using CO2SYS (Lewis and Wallace, 1998; van Heuven et al., 2011; Supplementary Table S1) and the dissociation constants of Mehrbach et al. (1973), as refitted by Dickson and Millero (1987), and Dickson (1990). The combined uncertainties in calculated inorganic carbon speciation were estimated numerically following Bevington and Robinson (2003). 


\subsection{Isotopic Analysis}

Cells were pelleted by centrifugation and stored at $-80{ }^{\circ} \mathrm{C}$. Values of $\delta^{13} \mathrm{C}_{\text {biomass }}$ were measured on thawed, acidified by wet $\mathrm{HCl}$ addition $(1 \mathrm{~N})$, and dried $\left(60^{\circ} \mathrm{C}\right)$ samples using an elemental analyzer interfaced to a continuous flow isotope ratio mass spectrometer (EA-IRMS; UC Davis Stable Isotope Facility). Alkenone $\delta^{13} \mathrm{C}$ values were measured from total lipid extracts (Bligh and Dyer, 1959) using gas chromatographyisotope ratio mass spectrometry (GC-IRMS: Thermo Scientific Delta V Advantage interfaced to a Trace GC Ultra via a GC Isolink). Alkenones were separated on a $60 \mathrm{~m}$ DB1-MS capillary column using the following oven ramp program: ramp from 65 to 110 ${ }^{\circ} \mathrm{C}$ at $40{ }^{\circ} \mathrm{C} / \mathrm{min}$ and hold $2 \mathrm{~min}$, ramp to $270^{\circ} \mathrm{C}$ at $40{ }^{\circ} \mathrm{C} / \mathrm{min}$, ramp to $320^{\circ} \mathrm{C}$ at 2 ${ }^{\circ} \mathrm{C} / \mathrm{min}$ and hold $36 \mathrm{~min}$. Values of $\delta^{13} \mathrm{C}$ were measured and averaged for $\mathrm{C}_{37: 3}$ and $\mathrm{C}_{37: 2}$ alkenones (peak sizes, $0.5 \mathrm{~V}-5 \mathrm{~V}, \mathrm{~m} / 244$; peak areas $8-131 \mathrm{Vs}$ ) using $n-\mathrm{C}_{32}, n-\mathrm{C}_{38}$, and $n-\mathrm{C}_{41}$ alkane external standards.

CAPs were isolated from freeze-dried biomass pellets according to the protocol described in Lee et al. (2016). Briefly, cells were cleaned with 1\% v/v Triton X-100, $4.5 \% \mathrm{v} / \mathrm{v} \mathrm{NaOCl}$ in $0.05 \mathrm{M} \mathrm{NaHCO}_{3}$. The coccoliths were centrifuged through a gradient of Ludox TM-50 colloidal silica (Sigma-Aldrich) layered with 20\% w/v sucrose. After additional rinses with $\mathrm{NH}_{4} \mathrm{HCO}_{3}$, the pellet was decalcified with $0.5 \mathrm{M}$ EDTA ( $\mathrm{pH}$ 8.0, $12 \mathrm{~h}$ ) and sonicated. Insoluble residues were removed by centrifugation and the supernatant was diafiltered with an Amicon Ultra-4 centrifugal filter unit to remove all molecules less than $14 \mathrm{kDA}$ (Millipore). The CAP was isolated by anion exchange liquid chromatography using a HiTrap DEAE FF (GE Healthcare). CAP extracts were subjected 
to sodium dodecyl sulfate polyacrylamide gel electrophoresis (SDS-PAGE) and PAGE, followed by staining with Alcian Blue to verify the presence of CAP and its existence as a single polysaccharide (Supplementary Fig. S1). CAP identity was also confirmed through reverse-phase high performance liquid chromatography (RP-HPLC) with apple pectin (polygalacturonic acid) as a positive control. Extracts were shown to be free of any contaminating proteins by performing a Bradford assay and by staining PAGE gels with Coomassie Blue. CAP $\delta^{13} \mathrm{C}$ values were analyzed by spooling wire micro-combustion isotope ratio mass spectrometry (SWiM-IRMS, Harvard University) using a pectin standard; full process blanks were assessed using both MilliQ water and the pectin standard.

$\delta^{13} \mathrm{C}$ values of DIC were measured at Woods Hole Oceanographic Institution on $\mathrm{CO}_{2}$ gas samples collected in Pyrex tubes following purification and DIC quantification on a vacuum line. Carbon isotope compositions of coccolith calcite were measured using a Thermo Delta V Advantage isotope ratio mass spectrometer fitted to a Kiel IV carbonate device (University of Oxford). All measured isotope values are reported on the international V-PDB scale. Carbon isotope fractionations between different cellular constituents are reported as simple linear differences $\left(\Delta \delta_{(\mathrm{A}-\mathrm{B})}=\delta^{13} \mathrm{C}_{\mathrm{A}}-\delta^{13} \mathrm{C}_{\mathrm{B}}\right)$ and as epsilon values (following Freeman and Hayes, 1992; Zeebe and Wolf-Gladrow, 2001): $\varepsilon_{(\mathrm{A}-\mathrm{B})}=\left(\delta^{13} \mathrm{C}_{\mathrm{A}}-\delta^{13} \mathrm{C}_{\mathrm{B}}\right) /\left(1+\delta^{13} \mathrm{C}_{\mathrm{B}} / 10^{3}\right)$.

\section{Results}

\subsection{Chemostat cultures}


Each experiment reached steady state for all measured variables 7-12 days after setting the initial conditions (dilution rate and $\mathrm{CO}_{2}$ combination). Multiple samples from the stable steady state were collected over the subsequent 3-6 days, treated as replicates, and averaged. Final cell densities were approximately $3 \times 10^{6}$ cells $/ \mathrm{mL}$ across experiments (Supplementary Table S2), as expected based on the low half-saturation constant for nitrate $\left(\mathrm{K}_{\mathrm{M}}=0.35 \mu \mathrm{M}\right.$; Perrin et al., 2016) relative to the initial concentration in the growth medium $(100 \mu \mathrm{M})$. Routine monitoring of residual nitrate concentrations indicated at least a 25 -fold reduction from the concentration in the feed media, yielding residual molar N:P ratios of less than 0.2 in all experiments (Supplementary Table S2). Dissolved $\mathrm{CO}_{2}$ concentrations (Table 1) were within the ranges of both the modern ocean $(\sim 8-30 \mu \mathrm{mol} / \mathrm{kg})$ and prior chemostat culture investigations of E. huxleyi (9.6-274.1 $\mu \mathrm{mol} / \mathrm{kg}$; Bidigare et al., 1997; Popp et al., 1998a,b). Growth rates ( $\mu$, Table1) were between 16 and $51 \%$ of the maximum growth rates achieved in nutrient-replete batch cultures ( $\mu_{\max }=1.22 / \mathrm{d}$; Hermoso et al., 2016a).

\subsection{Carbon isotopic compositions of cellular constituents and DIC}

Coccolith calcite was the most ${ }^{13} \mathrm{C}$-enriched cellular component, with $\delta^{13} \mathrm{C}$ values ranging from -15.4 to $-8.3 \%$ (Table 1). CAPs were the most enriched organic component ( -39.5 to $-38.2 \%)$, followed by bulk biomass ( -48.2 to $-39.5 \%$ ) and alkenones ( -51.5 to $-42.4 \%$ ) (Table 1$)$. The strongly negative absolute values of $\delta^{13} \mathrm{C}$ in all carbon pools reflect the influence of the tank $\mathrm{CO}_{2}(-38.58 \pm 0.03 \%)$ used to adjust the seawater carbonate chemistry. 
$\delta^{13} \mathrm{C}_{\mathrm{DIC}}$ values were measured for five consecutive sampling days at steady state during Experiment $\# 1$, with a mean value of $\delta^{13} \mathrm{C}_{\mathrm{DIC}}=-18.3 \pm 0.2 \%$. The isotopic composition of the dissolved $\mathrm{CO}_{2}(-27.8 \%)$ was calculated from $\delta^{13} \mathrm{C}_{\mathrm{DIC}}$ and carbonate speciation (Zeebe and Wolf-Gladrow, 2001), using the fractionation factors of Mook et al. (1974) and Zhang et al. (1995). Unfortunately, due to a technical malfunction, $\delta^{13} \mathrm{C}_{\mathrm{DIC}}$ measurements are unavailable for the remaining three experiments. However, the measurements from Experiment \#1 confirm that the fractionations expressed between DIC, biomass, and coccolith calcite are consistent with literature ranges. Photosynthetic carbon isotope fractionation $\left(\varepsilon_{\mathrm{P}}\right)$ was $21.4 \pm 1.5 \%$, calculated relative to $\mathrm{CO}_{2}$ as the inorganic carbon source, or $31.4 \%$ calculated relative to total DIC. This result agrees with Bidigare et al. (1997; Supplementary Fig. S2a), and falls within theoretical bounds established for eukaryotic phytoplankton (Goericke et al., 1994; Popp et al., 1998a; Wilkes et al., 2017). Interestingly, coccolith calcite is enriched by $2.9 \%$ relative to DIC in Experiment \#1 (and 1.9\%o relative to thermodynamic predictions for inorganically precipitated calcite, Romanek et al., 1992). This nearly 3\%o enrichment is at the upper end of the range reported from prior batch cultures of $E$. huxleyi $\left(\Delta \delta^{13} \mathrm{C}_{\text {calcite-DIC }}=-4.2\right.$ to 3\%; Rost et al., 2002; Ziveri et al., 2003; Hermoso et al., 2016b; Katz et al., 2017;

McClelland et al., 2017), likely reflecting differences in nutrient conditions and carbonate system manipulation between studies (see Section 4.1).

\subsection{Isotopic sensitivities to changing growth rate and $\left[\mathrm{CO}_{2(a q)}\right]$}

The $\delta^{13} \mathrm{C}$ values of bulk cellular biomass, calcite, and alkenones are influenced by the ratio $\mu /\left[\mathrm{CO}_{2(\mathrm{aq})}\right]$ (Bidigare et al., 1997; Popp et al., 1998a,b; Riebesell et al., 2000; 
Rost et al., 2002; Tchernov et al., 2014; Hermoso et al., 2016b; Holtz et al., 2017). These three cellular components, as well as CAPs, display strong linear relationships with respect to $\mu /\left[\mathrm{CO}_{2(\mathrm{aq})}\right]$ in this study $\left(r^{2}>0.90, p<0.05\right.$, Fig. 1a; Supplementary Fig. S2b). The $\delta^{13} \mathrm{C}$ values for each cellular pool grow increasingly ${ }^{13} \mathrm{C}$-enriched with increasing $\mu /\left[\mathrm{CO}_{2(\mathrm{aq})}\right]$, although not all pools have the same slope (Fig. 1a). $\delta^{13} \mathrm{C}_{\text {biomass }}$ and

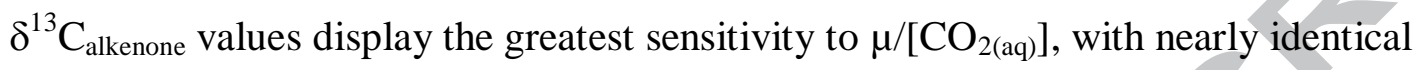
slopes of 190 and $202\left(\%\right.$ mol d)/kg, respectively. $\delta^{13} \mathrm{C}_{\text {calcite }}$ values display slightly less sensitivity with a slope of 157 , which corresponds to a $25 \%$ slope difference relative to $\delta^{13} \mathrm{C}_{\text {biomass. }} \delta^{13} \mathrm{C}_{\mathrm{CAP}}$ values respond least sensitively to $\mu /\left[\mathrm{CO}_{2(\mathrm{aq})}\right)$, with a slope of 75 (\%o $\mu \mathrm{mol} \mathrm{d}) / \mathrm{kg}$. When the $\delta^{13} \mathrm{C}$ values of alkenones and CAPs are compared to the bulk phases (calcite and biomass) the slopes of the cross-plots are approximately 1 and 0.5 , respectively (Fig. 1b,c).

The differences in isotopic sensitivities to $\mu /\left[\mathrm{CO}_{2(\mathrm{aq})}\right]$ are apparent by examining $\Delta \delta$ values, the isotopic differences between any two cellular carbon pools (Fig. 2). $\Delta \delta^{13} \mathrm{C}_{\text {calcite-CAP }}$ and $\Delta \delta^{13} \mathrm{C}_{\mathrm{CAP}-\text { biomass }}$ values both display robust linear relationships: with

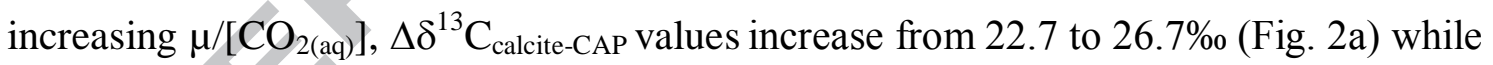

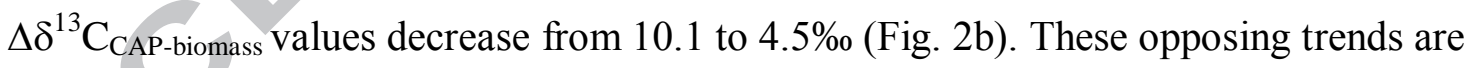
also evident in Fig. 1: $\delta^{13} \mathrm{C}_{\mathrm{CAP}}$ values approach $\delta^{13} \mathrm{C}_{\text {biomass }}$ values and diverge from $\delta^{13} \mathrm{C}_{\text {calcite }}$ values at the limit of faster growth or lower $\left[\mathrm{CO}_{2(\mathrm{aq})}\right]$.

Consistent with prior work, $\Delta \delta^{13} \mathrm{C}_{\text {biomass-alkenone values are constant within error }}$ across all four experiments, with a mean value of $3.5 \pm 0.5 \%$ (Table 2 ), and display no significant linear dependence on $\mu /\left[\mathrm{CO}_{2(\mathrm{aq})}\right]\left(r^{2}=0.20, p>0.05\right.$, Fig. 2c). Prior E. huxleyi chemostat cultures under analogous conditions $\left(\mu=0.2-0.6 / \mathrm{d}, 18^{\circ} \mathrm{C}\right.$, nitrate-limited $)$ 


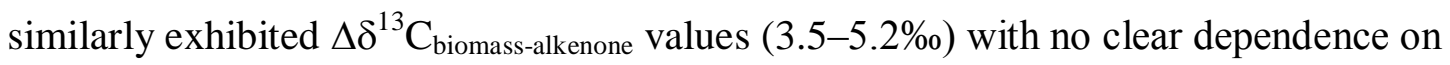
growth rate (Popp et al., 1998b). $\Delta \delta^{13} \mathrm{C}_{\text {calcite-biomass }}$ values also do not display a statistically significant response to $\mu /\left[\mathrm{CO}_{2(\mathrm{aq})}\right]$ ( $p>0.05$, Fig. $2 \mathrm{~d}$; mean $32.3 \pm 0.7 \%$ ). By analogy, therefore, the difference $\Delta \delta^{13} \mathrm{C}_{\text {calcite-alkenone would also be statistically constant over the }}$ range of the experiments; and collectively, the $\Delta \delta$ values indicate that biomass, alkenone, and calcite $\delta^{13} \mathrm{C}$ values all effectively respond similarly to $\mu /\left[\mathrm{CO}_{2 \text { (aq) }]}\right.$ (Fig. 1, 2). Only $\delta^{13} \mathrm{C}_{\mathrm{CAP}}$ values have a different $\mu /\left[\mathrm{CO}_{2(\mathrm{aq})}\right]$ sensitivity.

Maximum isotopic offsets between substrates and carbon pools occur at the limit of infinite $\left[\mathrm{CO}_{2(\mathrm{aq})}\right]$ or zero growth (Goericke et al., 1994; Laws et al., 1995). For example, $\varepsilon_{\mathrm{P}}$ values $\left(\approx \Delta \delta^{13} \mathrm{C}_{\mathrm{CO} 2 \text {-biomass }}\right)$ have an expected intercept of approximately $25 \%$, inferred from prior chemostat cultures of eukaryotic algae including E. huxleyi (Popp et al., 1998a). This value has been interpreted as the maximum fractionation accompanying enzymatic carbon fixation $\left(\varepsilon_{\mathrm{f}}\right)$. Although we were unable to measure $\delta^{13} \mathrm{C}_{\mathrm{DIC}}$ values for three of our experiments and thus cannot directly solve the $\varepsilon_{\mathrm{P}}=\varepsilon_{\mathrm{f}}-\mu /\left[\mathrm{CO}_{2(\mathrm{aq})}\right]$ equation in this study, the analogous intercept values for other carbon pools may provide insight into the inherent isotope effects of the governing reactions. $\Delta \delta^{13} \mathrm{C}_{\text {calcite-CAP }}$ approaches an intercept of approximately $22 \%, \Delta \delta^{13} \mathrm{C}_{\mathrm{CAP} \text {-biomass }}$ approaches $11 \%, \Delta \delta^{13} \mathrm{C}_{\text {biomass-alkenone }}$ approaches $4 \%$, and $\Delta \delta^{13} \mathrm{C}_{\text {calcite-biomass }}$ approaches $33 \%$.

\section{Discussion}

\subsection{Intracellular carbon isotope patterns - bulk classes}

The isotopic ordering among compound classes matches general expectations for photoautotrophs. Organic carbon is ${ }^{13} \mathrm{C}$-depleted relative to inorganic carbon (DIC and 
coccolith calcite) in our samples due to kinetic discrimination against ${ }^{13} \mathrm{CO}_{2}$ during photosynthesis (e.g., Goericke et al., 1994). Within the organic carbon pools, typical intracellular isotopic ordering also prevails: carbohydrates are more enriched in ${ }^{13} \mathrm{C}$ than total cellular biomass, while lipids are ${ }^{13}$ C-depleted (Wong et al., 1975; Sakata et al., 1997; Hayes, 2001). This consistent isotopic pattern $\left(\delta^{13} \mathrm{C}_{\mathrm{CAP}}>\delta^{13} \mathrm{C}_{\text {biomass }}>\delta^{13} \mathrm{C}_{\text {alkenone }}\right)$ can be explained by a biosynthetic reaction network in which simple carbohydrates, used to synthesize CAPs, are the first compounds generated, while downstream kinetic processes discriminate against ${ }^{13} \mathrm{C}$ and produce relatively ${ }^{13} \mathrm{C}$-depleted products including alkenones (Hayes, 2001).

All $\Delta \delta$ values (Fig. 2) are also consistent with expectations. Our mean

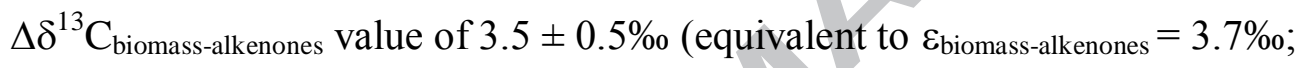
Supplementary Table S3) is within error, although on the lower end, of the $3.8-4.2 \%$ corrections that have been implemented in paleobarometry studies (Jasper and Hayes, 1990; Jasper et al., 1994; Pagani et al., 2005; Bijl et al., 2010; Seki et al., 2010) and is typical of the expressed fractionation for acetogenic lipids relative to total biomass (e.g., Hayes, 2001).

Paired measurements of calcite and biomass $\delta^{13} \mathrm{C}$ values from the same study are rare. Our mean $\Delta \delta^{13} \mathrm{C}_{\text {calcite-biomass }}$ value of $32.3 \pm 0.7 \%$ (equivalent to $\varepsilon_{\text {calcite-biomass }}=33.8 \pm$ 0.9\%o; Supplementary Table S3) exceeds the values measured in two nutrient-replete batch culture studies of E. huxleyi $\left(\Delta \delta^{13} \mathrm{C}_{\text {calcite-biomass }}=15.3-28.8 \%\right.$, Rost et al., 2002; McClelland et al., 2017), but the difference must partially reflect the larger $\varepsilon_{\mathrm{P}}$ values obtained in nitrate-limited chemostats $\left(\varepsilon_{P}=21.4 \%\right.$, Experiment $\# 1 ; 17.2-24.9 \%$ in Bidigare et al., 1997; Supplementary Fig. S2a) relative to those from the batch cultures 
$\left(\varepsilon_{\mathrm{P}}=6.7-17.1 \%\right.$, Rost et al., 2002; McClelland et al., 2017). The larger fractionations in our study may also result from the continuous, relatively high light conditions employed (associated with larger $\varepsilon_{\mathrm{P}}$ values: Rost et al., 2002; Holtz et al., 2017) and differences in carbonate system manipulation between studies (McClelland et al., 2017).

No prior investigations have characterized the carbon isotope fractionation between CAPs and other cellular pools; and interestingly, the $\Delta \delta$ values we observe for CAPs appear to be different from expectations for bulk carbohydrates. Bulk carbohydrates can be up to 3-4\% enriched relative to total biomass for photoautotrophs, but more commonly are thought to be on average 1-2\%o enriched (Abelson and Hoering, 1961; Coffin et al., 1990; Macko et al., 1990; Hayes, 2001). However, analyses of individual monosaccharides indicate substantial isotopic heterogeneity within the bulk carbohydrate pool, with some being significantly enriched in ${ }^{13} \mathrm{C}$ (van Dongen et al.,

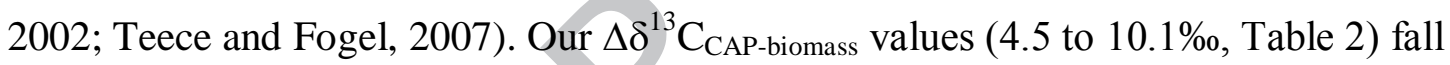
within ranges observed for individual monosaccharides in marine and freshwater algae (0-9\% for unicellular algae, and up to $13 \%$ for the macroalgal species Ulva lactuca: van Dongen et al., 2002; Teece and Fogel, 2007). Teece and Fogel (2007) measured $\delta^{13} \mathrm{C}$ values for glucose and galactose from a batch culture of E. huxleyi, finding enrichments of 5 and $7 \%$ relative to biomass, respectively, and leading to predictions of

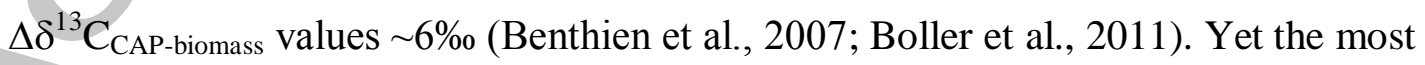
prevalent monomers within the CAP structure (mannose, galacturonic acid, and rhamnose: Fichtinger-Schepman, 1981) have not to date been isotopically characterized for this species. In a field specimen of Ulva lactuca, these monomers were ${ }^{13} \mathrm{C}$-enriched relative to biomass by $10 \%$ (mannose), 13\% (galactose), and 7\%o (rhamnose) (Teece and 
Fogel, 2007). Because our $\Delta \delta^{13} \mathrm{C}_{\mathrm{CAP}-\text { biomass }}$ values of $4.5-10.1 \%$ are broadly consistent with these existing measurements, it is likely that $\delta^{13} \mathrm{C}_{\mathrm{CAP}}$ values are more ${ }^{13} \mathrm{C}$-enriched than the mass-weighted average carbohydrate composition of the cells, perhaps to an even greater extent than predicted by Benthien et al. (2007) and Boller et al. (2011).

\subsection{Linear isotopic responses to changing $\mu /\left[\mathrm{CO}_{2(a q)}\right]$}

The linear increase in $\delta^{13} \mathrm{C}_{\text {biomass }}$ values with increasing $\mu /\left[\mathrm{CO}_{2 \text { (aq) }}\right]$ (Fig. 1) is consistent with predictions from simple algal models invoking primarily diffusive entry of $\mathrm{CO}_{2}$ into the cell for photosynthetic fixation (e.g., Freeman and Hayes, 1992; Laws et al., 1995). Bidigare et al. (1997) showed similar linear increases in $\delta^{13} \mathrm{C}_{\text {biomass }}$ values under analogous chemostat growth conditions (Supplementary Fig. S2b). While it is not necessary to invoke non-diffusive carbon supply to explain either chemostat study, $\delta^{13} \mathrm{C}_{\text {biomass }}$ values cannot be used to rule out the use of carbon concentrating mechanisms (CCMs) in E. huxleyi. Laws et al. (2002) hypothesized that the $\delta^{13} C_{\text {biomass }}$ values of $E$. huxleyi should become insensitive to the ratio $\mu / \mathrm{CO}_{2}$ at values exceeding $\sim 0.1$ $\mathrm{kg} /(\mu \mathrm{mol} / \mathrm{d})$ if an inducible carbon concentrating mechanism (CCM) is employed (assuming a cell radius of $2.6 \mu \mathrm{m}$ and a permeability of $10^{-5} \mathrm{~m} / \mathrm{s}$ ). Neither Bidigare et al. (1997) nor the present study tested $\mu / \mathrm{CO}_{2}$ values larger than $0.07 \mathrm{~kg} /(\mu \mathrm{mol} \mathrm{d})$. Indeed, substantial physiological evidence indicates that $E$. huxleyi uses a variety of CCMs to actively enhance intracellular $\mathrm{CO}_{2}$ (e.g., Rost et al., 2006; Mackinder et al., 2011; Bach et al., 2013; Isensee et al., 2014). We also cannot rule out the possibility that changes in $\delta^{13} \mathrm{C}_{\mathrm{DIC}}$ contributed to the variation in $\delta^{13} \mathrm{C}_{\text {biomass }}$ that we observe. Distinct $\mathrm{CO}_{2}$ conditions were achieved by bubbling with varying amounts of isotopically depleted tank $\mathrm{CO}_{2}$ and 
$\mathrm{N}_{2}: \mathrm{O}_{2}$. Under higher $\left[\mathrm{CO}_{2(\mathrm{aq})}\right], \delta^{13} \mathrm{C}_{\text {biomass }}$ values may therefore be driven lighter, in part, by a depleted isotopic composition of DIC. Notably, the carbonate system chemistry in Bidigare et al. (1997) was manipulated in a similar manner and yielded linear responses of both $\delta^{13} \mathrm{C}_{\text {biomass }}$ and $\varepsilon_{\mathrm{P}}$ values to $\mu /\left[\mathrm{CO}_{2 \text { (aq) }}\right]$ (Supplementary Fig. S2).

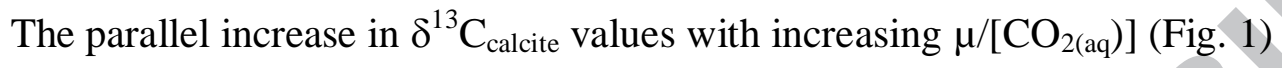
suggests that a common physiological mechanism governs the isotopic signature of both calcite and biomass. Photosynthesis discriminates against ${ }^{13} \mathrm{C}$ in the chloroplast, producing depleted $\delta^{13} \mathrm{C}_{\text {biomass }}$ values while simultaneously enriching ${ }^{13} \mathrm{C}$ in the remaining intracellular DIC pool. If this enriched DIC is also used for calcification, $\delta^{13} \mathrm{C}_{\text {calcite }}$ and $\delta^{13} \mathrm{C}_{\text {biomass }}$ values might both be expected to increase in response to increasing $\mu /\left[\mathrm{CO}_{2(\mathrm{aq})}\right]$, consistent with our observed constant value for $\Delta \delta^{13} \mathrm{C}_{\text {calcite-biomass }}(32.3 \pm 0.7 \%$; Table 2) and measurements of other lightly calcifying coccolithophores (Hermoso et al., 2016b; McClelland et al., 2017). In species with higher ratios of particulate inorganic to organic carbon (high PIC:POC ratios), $\delta^{13} \mathrm{C}_{\text {calcite }}$ values would instead be expected to decrease

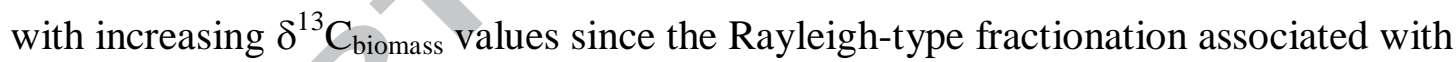
calcification within the coccolith vesicle would obscure the chloroplast-derived fraction of the signal (Hermoso et al., 2016b; McClelland et al., 2017).

Similar reasoning also explains the linear responses of the organic compound classes (alkenones and CAPs) to $\mu /\left[\mathrm{CO}_{2(\mathrm{aq})}\right]$, but it cannot explain why the slope of the $\delta^{13} \mathrm{C}$ vs $\mu /\left[\mathrm{CO}_{2(\mathrm{aq})}\right]$ signature is not conserved in the CAPs (Fig. 1). Under high utilization of $\mathrm{CO}_{2}$ (larger values for $\left.\mu /\left[\mathrm{CO}_{2(\text { aq }}\right]\right)$ ), $\delta^{13} \mathrm{C}_{\mathrm{CAP}}$ values appear to be approaching $\delta^{13} \mathrm{C}_{\text {biomass }}$ values, while at very low utilization, the value of $\Delta \delta^{13} \mathrm{C}_{\mathrm{CAP}-\text { biomass }}$ has a predicted maximum of $11 \% 0$ (y-axis intercept, Fig. 2b). This changing signature specifically 
indicates that $\delta^{13} \mathrm{C}_{\mathrm{CAP}}$ values are approximately half as sensitive as the other cellular components to the ratio $\mu /\left[\mathrm{CO}_{2(\mathrm{aq})}\right]$, and it points towards a more complex control on the isotopic composition of this polymer.

\subsection{Physiological interpretation of $\delta^{13} C_{C A P}$ patterns}

The fractionation between CAPs and biomass $\left(\Delta \delta^{13} \mathrm{C}_{\mathrm{CAP}-\text { biomass }}\right)$ spans a $5.6 \%$ range without any compensatory change in $\Delta \delta^{13} \mathrm{C}_{\text {alkenone-biomass values. This could occur if }}$ isotopically distinct carbohydrate pools exist within E. huxleyi and the relative amount of carbon flowing to these pools varies systematically with growth conditions. Simple assumptions about cellular composition are used to illustrate this hypothesis, following Hayes (2001).

$\delta^{13} \mathrm{C}_{\text {biomass }}$ values can be decomposed into the fractional allocation of cellular carbon to the major organic compound classes, as well as the mass-weighted average isotopic composition of each class (Eqn. 1). The subscripts in Equation 1 correspond to proteins, carbohydrates, and lipids, respectively; $f$ is the fractional flux of fixed carbon flowing to each compound class at steady state. We also assume that the bulk carbohydrate pool, denoted $\delta_{\text {carb }}$, results from the balance of two distinct carbohydrate fractions: acidic polysaccharides $\left(f_{\mathrm{CAP}}\right)$ and other saccharides $\left(f_{\text {sacc }}\right)($ Eqn. 2$)$.

$\delta_{\text {biomass }}=f_{\text {prot }} \delta_{\text {prot }}+f_{\text {carb }} \delta_{\text {carb }}+f_{\text {lip }} \delta_{\text {lip }}$

$\delta_{\mathrm{carb}}=f_{\mathrm{CAP}} \delta_{\mathrm{CAP}}+f_{\mathrm{sacc}} \delta_{\mathrm{sacc}}$

Values of $\delta_{\text {biomass }}$ and $\delta_{\mathrm{CAP}}$ correspond to the values listed in Table 1 , and $\delta_{\text {lip }}$ values are estimated to be $4 \%{ }^{13} \mathrm{C}$-depleted relative to biomass $\left(\delta_{\text {lip }}=\delta_{\text {biomass }}-4 \%\right.$, Eqn. 3, Table 3) by analogy with our $\delta^{13} \mathrm{C}_{\text {alkenones }}$ measurements and other consensus 
observations (e.g., Schouten et al., 1998; Laws et al., 2001). Alkenones and total lipids are assumed to be isotopically equivalent because alkenones represent a significant fraction of the lipids synthesized in E. huxleyi. Quantitative analyses of carbon fluxes show that up to $18 \%$ of photosynthetic carbon is dedicated to alkenones in cells harvested from batch cultures (Tsuji et al., 2015). We further assume that proteins and biomass would be isotopically equal $\left(\delta_{\text {prot }}=\delta_{\text {biomass }}\right)$, since proteins are expected to represent the majority of total cell carbon (e.g., Hayes, 2001; Tang et al., 2017). Finally, $\delta_{\text {carb, }}$ representing the total combined carbohydrate fraction in the cell, is assumed to be enriched by $4 \%$ relative to biomass $\left(\delta_{\text {carb }}=\delta_{\text {biomass }}+4 \%\right.$; Eqn. 3 , Table 3$)$. This assumption is at the upper end of the range reported for bulk carbohydrates in other autotrophs (Wong et al., 1975; van der Meer et al., 2001; van Dongen et al., 2002). $\delta_{\text {biomass }}=f_{\text {prot }}\left(\delta_{\text {biomass }}\right)+f_{\text {carb }}\left(\delta_{\text {biomass }}+4 \%\right)+f_{\text {lip }}\left(\delta_{\text {biomass }}-4 \%\right.$ o $)$

Solving Eqn 3 requires an estimate of one fractional flux, so we estimate $f_{\text {lip }}=$ 0.25 by considering how biosynthesis affects the carbon isotopic composition of $n$-alkyl lipids. Acetyl-coenzyme A $(\mathrm{CoA})$ is produced from the decarboxylation of pyruvate by the enzyme pyruvate dehydrogenase. This step is accompanied by an isotope effect of $\sim 23 \%$, generating a ${ }^{13} \mathrm{C}$-depleted carboxyl group relative to the methyl group in acetyl-CoA (Monson and Hayes, 1982; Hayes, 2001). This translates to a $\sim 12 \%$ depletion for the overall acetyl-CoA molecule relative to pyruvate. However, the net isotopic composition of the resulting acetogenic lipids relative to biomass is controlled by the branching ratio of pyruvate destined for lipid synthesis vs that used directly, either for cellular biosynthesis or for carboxylation to oxaloacetate by anaplerotic reactions. In the absence of anaplerotic reactions, an expressed 4\%o depletion in lipids relative to biomass 
would indicate allocation of $\sim 33 \%$ of pyruvate to lipid synthesis, but accounting for additional anaplerotic fluxes (e.g., Tang et al., 2017) decreases this estimate to 25\%.

Proteins and carbohydrates must together constitute the remaining biomass (75\%) in Eqn. 3, allowing us to solve for the remaining unknowns. We find that bulk cellular carbon allocation remains invariant across our experiments: $f_{\text {lip }}=0.25, f_{\text {prot }}=0.5, f_{\text {carb }}=$ 0.25 (Table 3, Fig. 3a,b). This finding is plausible but prescribed by the assumptions of the model: mass balance calculations with constant isotopic offsets between pools will result in constant allocation to $f_{\text {carb }}$ and $f_{\text {prot }}$ regardless of choice of $f_{\text {lip. }}$. For example, other reasonable choices for $f_{\text {lip }}$ (ranging from $0.15-0.33$ ) are explored in Supplementary Table $\mathrm{S} 4$, producing different fractional carbon allocations to $f_{\text {prot }}(0.7-0.33)$ and $f_{\text {carb }}$ $(0.15-0.33)$.

The fractional allocation to CAPs $\left(f_{\text {CAP }}\right)$ vs other saccharides $\left(f_{\text {sacc }}\right)$ is calculated by assuming a net fractionation factor between the two pools $\left(\Delta \delta_{\mathrm{CAP}-\mathrm{sacc}}\right)$ of $7 \%$ (Eqn. 4 , Table 3). This value corresponds to the maximum $\Delta \delta^{13} \mathrm{C}_{\text {CAP-biomass value of } 11 \% \text { inferred }}$ from the y-intercept of Fig. 2 b, corrected by $4 \%$ to account for our assumption that $\delta_{\text {carb }}$ is $4 \%$ enriched relative to $\delta_{\text {biomass }}($ Eqn. 3$)$.

$\delta_{\text {carb }}=\delta_{\text {biomass }}+4 \%$ o $=f_{\mathrm{CAP}} \delta_{\mathrm{CAP}}+\left(1-f_{\mathrm{CAP}}\right)\left(\delta_{\mathrm{CAP}}-7 \%\right.$ o $)$

The $f_{\text {CAP }}$ results (Table 3 ) indicate that the total cellular carbon allocation to CAPs increases from 3.5 to $22.8 \%$ from Experiment \#1 to \#4, in agreement with ${ }^{14} \mathrm{C}$-labeling experiments showing that $\sim 15-20 \%$ of fixed carbon is used for the synthesis of acidic polysaccharides in E. huxleyi (Kayano and Shiraiwa 2009; Tsuji et al., 2015; Taylor et al., 2017). 
To test the sensitivity of our model results, other plausible choices of $\delta_{\text {prot }}$ and $\delta_{\text {carb }}$ inputs are evaluated in Table 3, Fig. 3b, and Supplementary Fig. S3; all cases suggest that E. huxleyi produces more CAPs relative to other carbohydrates as $\mu /\left[\mathrm{CO}_{2(\mathrm{aq})}\right]$ increases (Table 3, Fig. 3a,b). It remains unknown whether this response in our cultures is a consequence of the faster growth rate or the relatively lower $\mathrm{CO}_{2}$ concentrations under these conditions. Several studies imply that E. huxleyi regulates carbon flow among CAPs, neutral polysaccharides, and low molecular weight (LMW) metabolites in response to changing growth conditions (Kayano and Shiraiwa, 2009; Borchard and Engel, 2012; Chow et al., 2015). Most of these studies have been conducted with batch cultures or phosphorous-limited chemostat cultures, so as yet no corroborating evidence for nitrate-limited conditions exists. However, our estimates are consistent with ${ }^{14} \mathrm{C}$-labeling experiments with the green alga Dunaliella tertiolecta in nitrate-limited chemostat cultures (Halsey et al., 2011), which showed that at faster growth rates, proportionally more ${ }^{14} \mathrm{C}$ is allocated to polysaccharides, and at slower growth rates, more ${ }^{14} \mathrm{C}$ is allocated to LMW metabolites. For E. huxleyi, this may reflect a strategy by the cell to support calcification when the intracellular carbon pool is relatively depleted.

Alternatively, our data might imply that CAPs are synthesized from proportionally more recycled cellular carbon with increasing growth rates. If proteins are recycled for the synthesis of CAPs, and $\delta_{\text {prot }} \approx \delta_{\text {biomass, }}$ then CAP and biomass $\delta^{13} \mathrm{C}$ values would be expected to converge with enhanced recycling. However, such explanation requires that the recycled carbon be incorporated at a biosynthetic stage downstream of simple sugars and prior to the polymerization of CAPs. If the recycled carbon first passed through simple sugars, then no difference in slopes would result among organic 
compound classes since simple sugars are precursors to proteins and lipids, as well as CAPs. One additional possibility is that the monosaccharide composition may have changed systematically with the changing growth conditions. Only one polysaccharide was detected per extract by PAGE, SDS-PAGE, and HPLC, but we did not explicitly verify that the monosaccharide composition of the CAP remained constant across experiments. Future studies could clarify this contribution by comparing the isotopic composition of CAPs with that of individual monomers from the same extract.

\section{Conclusions: Implications for paleoceanography}

Our findings indicate that alkenones have greater inherent sensitivity for paleobarometry applications than CAPs due to the steeper slope relating $\delta^{13} \mathrm{C}_{\text {alkenones }}$ values to $\mu /\left[\mathrm{CO}_{2(\mathrm{aq})}\right]$ (Fig. 1). The relatively constant isotopic depletion in alkenones compared to biomass across four growth conditions supports the conclusions of Popp et al. (1998b) that growth rate does not significantly or systematically influence the isotopic offset between bulk biomass and alkenones. This result upholds the fundamental assumption employed in alkenone-based $p \mathrm{CO}_{2}$ reconstructions that sedimentary $\delta^{13} \mathrm{C}_{\text {alkenone }}$ measurements can be used to estimate original $\delta^{13} \mathrm{C}_{\text {biomass }}$ values. In contrast, CAPs are not direct analogues or replacements for alkenone biomarkers in the reconstruction of $\delta^{13} \mathrm{C}_{\text {biomass }}$ values, since $\Delta \delta^{13} \mathrm{C}_{\text {biomass-CAP varies by }}$ $5.6 \%$ in our experiments. This is a large variation relative to the limited range of investigated growth and $\left[\mathrm{CO}_{2(\mathrm{aq})}\right]$ conditions. However, assuming that our chemostat results are applicable to in situ processes in both ancient and modern environments, then alkenones, calcite, and CAPs all recovered from the same sedimentary deposit may 
together be more useful than alkenones and calcite alone: isotopic measurements of all three cellular constituents would constrain $\mu /\left[\mathrm{CO}_{2(\mathrm{aq})}\right]$ with fewer assumptions than current approaches using the $\left[\mathrm{PO}_{4}{ }^{3-}\right]$-derived " $b$ " parameter (Rau et al., 1992; Bidigare et al., 1997). If the alkenones, calcite, and CAPs are related by $\Delta \delta$ values that map onto Fig. $2 \mathrm{a}$ and $2 \mathrm{~b}$, this information reconstructs $\mu /\left[\mathrm{CO}_{2(\mathrm{aq})}\right]$ directly. One advantage of this approach is that it does not require seawater $\delta^{13} \mathrm{C}_{\mathrm{DIC}}$ values, enabling reconstructions from sediments lacking coeval planktonic foraminifera. Another advantage is the potential to recover additional useful information about the coccolithophore community through parallel efforts. CAPs are extracted from fossilized coccoliths, so cell size and taxonomy information should be recoverable with coccolith calcite and CAP isotope values (Henderiks, 2008; Bolton et al., 2012; Bolton and Stoll, 2013; O’Dea et al., 2014; McClelland et al., 2016). The uronic acid contents of CAPs provide complementary information about the internal saturation state of the coccolith vesicle and, by extension, atmospheric $\mathrm{CO}_{2}$ levels (Lee et al., 2016; Rickaby et al., 2016). If $\delta^{13} \mathrm{C}_{\text {DIC }}$ can be estimated using independent measurements (e.g., mixed-layer foraminifera), then measurements of either $\Delta \delta^{13} \mathrm{C}_{\mathrm{CAP}-\text { alkenone }}$ or $\Delta \delta^{13} \mathrm{C}_{\text {calcite-CAP }}$ could be used to reconstruct $\delta^{13} \mathrm{C}_{\text {biomass. }}$ Together these strategies point to a way forward for paleobarometry: by analyzing a suite of geologically preserved constituents, including CAPs, it may be possible to reduce some of the uncertainties inherent to any single proxy approach. Thus, with additional proxy validation efforts, including cultures and field studies encompassing other species and $\mathrm{CO}_{2}$ conditions, the carbon isotopic composition of CAPs may provide an important biochemical window into ancient environments. 


\section{Acknowledgements}

This work was supported by a National Science Foundation Graduate Research

Fellowship [grant number DGE1144152, to EBW]; the Gordon and Betty Moore

Foundation (to AP); and NASA-NAI CAN6 (to AP; PI Roger Summons, MIT). We thank

Susie Carter, Katie Mabbott, and Alan Gagnon for assistance with laboratory analyses,

Einat Segev for providing starter cultures and culturing advice, John Volkman and Bart van Dongen for editorial handling, and two anonymous reviewers for their thoughtful comments.

\section{Associate Editor-Bart van Dongen}

\section{References}

Abelson, P.H., Hoering, T.C., 1961. Carbon isotope fractionation in formation of amino acids by photosynthetic organisms. Proceedings of the National Academy of Sciences of the United States of America 47, 623-632.

Bach, L.T., Mackinder, L.C.M., Schulz, K.G., Wheeler, G., Schroeder, D.C., Brownlee, C., Riebesell, U., 2013. Dissecting the impact of $\mathrm{CO}_{2}$ and $\mathrm{pH}$ on the mechanisms of photosynthesis and calcification in the coccolithophore Emiliania huxleyi. New Phytologist 199, 121-134.

Benthien, A., Zondervan, I., Engel, A., Hefter, J., Terbrüggen, A., Riebesell, U., 2007. Carbon isotopic fractionation during a mesocosm bloom experiment dominated by Emiliania huxleyi: Effects of $\mathrm{CO}_{2}$ concentration and primary production.

Geochimica et Cosmochimica Acta 71, 1528-1541. 
Bevington P.R., Robinson, D.K., 2003. Data reduction and error analysis for the physical sciences, second ed. McGraw-Hill, New York.

Bidigare, R.R., Fluegge, A., Freeman, K.H., Hanson, K.L., Hayes, J.M., Hollander, D., Jasper, J.P., King, L.L., Laws, E.A., Milder, J., Miller, F.J., Pancost, R., Popp, B.N., Steinberg, P.A., Wakeham, S.G., 1997. Consistent fractionation of ${ }^{13} \mathrm{C}$ in nature and in the laboratory: Growth-rate effects in some haptophyte algae. Global Biogeochemical Cycles 11, 279-292.

Bijl, P.K., Houben, A.J.P., Schouten, S., Bohaty, S.M., Sluijs, A., Reichart, G.J., Sinninghe Damsté, D.S., Brinkhuis, H., 2010. Transient middle Eocene atmospheric $\mathrm{CO}_{2}$ and temperature variations. Nature 330, 819-821.

Bligh, E.G., Dyer, W.J., 1959. A rapid method of total lipid extraction and purification. Canadian Journal of Biochemistry and Physiology 37, 911-919.

Boller, A.J., Thomas, P.J., Cavanaugh, C.M., Scott, K.M., 2011. Low stable carbon isotope fractionation by coccolithophore RubisCO. Geochimica et Cosmochimica Acta $75,7200-7207$.

Bolton, C.T., Stoll, H.M., 2013. Late Miocene threshold response of marine algae to carbon dioxide limitation. Nature 500, 558-562.

Bolton, C.T., Stoll, H.M., Mendez-Vicente, A., 2012. Vital effects in coccolith calcite: Cenozoic climate $p \mathrm{CO}_{2}$ drove the diversity of carbon acquisition strategies in coccolithophores? Paleoceanography 27, PA4204.

Borchard, C., Engel, A., 2012. Organic matter exudation by Emiliania huxleyi under simulated future ocean conditions. Biogeosciences 9, 3405-3423. 
Borman, A.H., de Jong, E.W., Huizinga, M., Kok, D.J., Westbroek P., Bosch L., 1982. The role in $\mathrm{CaCO}_{3}$ crystallization of an acid $\mathrm{Ca}^{2+}$-binding polysaccharide associated with coccoliths of Emiliania huxleyi. European Journal of Biochemistry 129, 179-183.

Bown, P.R., 1987. Taxonomy, biostratigraphy, and evolution of late Triassic-early Jurassic calcareous nannofossils. Special Papers in Palaeontology 38, 1-18.

Brassell, S.C., 2014. Climatic influences on the Paleogene evolution of alkenones. Paleoceanography 29, 255-272.

Chow, J.S., Lee, C., Engel, A., 2015. The influence of acidic polysaccharides, growth rate, and free coccoliths on the coagulation efficiency of Emiliania huxleyi. Marine Chemistry 175, 5-17.

Coffin, R.B., Velinsky, D.J., Devereux, R. Price, W.A., Cifuentes, L.A., 1990. Stable carbon isotope analysis of nucleic acids to trace sources of dissolved substrates used by estuarine bacteria. Applied Environmental Microbiology 56, 2012-2020.

De Jong, E.W., Bosch, L., Westbroek, P., 1976. Isolation and characterization of a $\mathrm{Ca}^{2+}$-binding polysaccharide associated with coccoliths of Emiliania huxleyi (Lohmann) Kamptner. European Journal of Biochemistry 70, 611-612.

De Vargas, C., Aubry, M.-P., Probert, I., Young, J., 2007. Origin and evolution of coccolithophores: From coastal hunters to oceanic farmers. In: Falkowski, K, Knoll, A. (Eds.), Evolution of Primary Producers in the Sea. Elsevier, Boston, pp. $133-163$. 
Dickson, A.G., 1990. Standard potential of the reaction: $\mathrm{AgCl}(\mathrm{s})+1 / 2 \mathrm{H}_{2}(\mathrm{~g})=\mathrm{Ag}(\mathrm{s})+$ $\mathrm{HCl}(\mathrm{aq})$, and the standard acidity constant of the ion $\mathrm{HSO}_{4}{ }^{-}$in synthetic seawater from 273.15 to $318.15 \mathrm{~K}$. The Journal of Chemical Thermodynamics 22,113-127.

Dickson, A.G., Millero, F.J., 1987. A comparison of the equilibrium constants for the dissociation of carbonic acid in seawater media. Deep Sea Research Part I 34, $1733-1743$.

Dickson, A.G., Sabine, C.L., Christian, J.R., 2007. Guide to best practices for ocean $\mathrm{CO}_{2}$ measurements. PICES Special Publication 3, 1-191.

Farrimond P., Eglinton, G., Brassell, S.C., 1986. Alkenones in Cretaceous black shales, Blake-Bahama Basin, western North Atlantic. Organic Geochemistry 10, 897903.

Fichtinger-Schepman, A.M., Kamerling, J.P., Versluis, C., Vliegenthart, F.G., 1981. Structural studies of the methylated, acidic polysaccharide associated with coccoliths of Emiliania huxleyi (Lohmann) Kamptner, 1981. Carbohydrate Research 93, 105-123.

Freeman, K.H., Hayes, J.M., 1992. Fractionation of carbon isotopes by phytoplankton and estimates of ancient $\mathrm{CO}_{2}$ levels. Global Biogeochemical Cycles 6, 185-198.

Goericke, R., Montoya, J., Fry, B., 1994. Physiology of isotopic fractionation in algae and cyanobacteria. In: Lajtha, K., Michener, R. (Eds.), Stable Isotopes in Ecology and Environmental Science. Blackwell Scientific Publications, Oxford, pp. 187221.

Gran, G., 1952. Determination of the equivalence point in potentiometric titrations, Part II. Analyst 77, 661-671. 
Guillard, R.R.L., Hargraves, P.E., 1993. Stichochrysis immobilis is a diatom, not a chrysophyte. Phycologia 32, 234-236.

Halsey, K.H., Milligan, A.J., Behrenfeld, M.J., 2011. Linking time-dependent carbon-fixation efficiencies in Dunaliella tertiolecta (Chlorophyceae) to underlying metabolic pathways. Journal of Phycology 47, 66-76.

Hayes, J.M., 2001. Fractionation of carbon and hydrogen isotopes in biosynthetic processes. Reviews in Mineralogy and Geochemistry 43, 225-277.

Henderiks, J., 2008. Coccolithophore size rules - Reconstructing ancient cell geometry and cellular calcite quota from fossil coccoliths. Marine Micropaleontology 67, $143-154$.

Henriksen, K., Stipp, S.L.S., 2009. Controlling biomineralization: The effect of solution composition on coccolith polysaccharide functionality. Crystal Growth and Design 9, 2088-2097.

Hermoso, M., 2014. Coccolith-derived isotopic proxies in palaeoceanography: where geologists need biologists. Cryptogamie, Algologie 35, 323-351.

Hermoso, M., Rickaby, R.E.M, Minoletti, F. Diester-Haas, L., 2009. The Middle Miocene paleoceanographic events as seen by the chemistry of calcareous nannofossils in SW Pacific Ocean. Eos Transactions AGU 90, PP41A-1498.

Hermoso, M., Minoletti, F., Aloisi, G., Bonifacie, M., McClelland, H.L.O., Labourdette, N., REnforth, P., Chaduteau, C., Rickaby, R.E.M., 2016a. An explanation for the ${ }^{18} \mathrm{O}$ excess in Noelaerhabdaceae coccolith calcite. Geochimica et Cosmochimica Acta 189, 132-142. 
Hermoso, M., Chan, I.Z.X., McClelland, H.L.O., Heureux, A.M.C., Rickaby, R.E.M., 2016b. Vanishing coccolith vital effects with alleviated carbon limitation. Biogeoscience 13, 301-312.

Holtz, L.-M., Wolf-Gladrow, D., Thoms, S., 2017. Stable carbon isotope signals in particulate organic and inorganic carbon of coccolithophores - A numerical model study for Emiliania huxleyi. Journal of Theoretical Biology 420, 117-127.

Isensee, K., Erez, J., Stoll, H.M., 2014. Detection of a variable intracellular acid-labile carbon pool in Thalassiosira weissflogii (Heterokontophyta) and Emiliania huxleyi (Haptophyta) in response to changes in the seawater carbon system. Physiologia Plantarum 150, 321-338.

Jasper, J.P., Hayes, J.M., 1990. A carbon isotope record of $\mathrm{CO}_{2}$ levels during the late Quaternary. Nature 347, 462-464.

Jasper, J.P, Hayes, J.M., Mix, A.C., Prahl, F.G., 1994. Photosynthetic fractionation of ${ }^{13} \mathrm{C}$ and concentrations of $\mathrm{CO}_{2}$ in the central equatorial Pacific during the last 225,000 years. Paleoceanography $9,781-898$.

Katz, A., Bonifacie, M., Hermoso, M., Cartigny, P., Calmels, D., 2017. Laboratory-grown coccoliths exhibit no vital effect in clumped isotope $\left(\Delta_{47}\right)$ composition on a range of geologically relevant temperatures. Geochimica et Cosmochimica Acta 208, 335-353.

Kayano, K., Shiraiwa, Y., 2009. Physiological regulation of coccolith polysaccharide production by phosphate availability in the coccolithophorid Emiliania huxleyi. Plant Cell Physiology 50, 1522-1531. 
Kok, D.J., Blomen, L.J.M.J., Westbroek, P., Bijvoet, O.L.M., 1986. Polysaccharide from coccoliths $\left(\mathrm{CaCO}_{3}\right.$ biomineral): influence on crystallization of calcium oxalate monohydrate. European Journal of Biochemistry 158, 167-172.

Laws, E.A., Popp, B.N., Bidigare, R.R., Kennicutt, M.C., Macko, S.A., 1995. Dependence of phytoplankton carbon isotopic composition on growth rate and $\mathrm{CO}_{2 a q}$ : theoretical considerations and experimental results. Geochimica et Cosmochimica Acta 59, 1131-1138.

Laws, E.A., Popp, B.N., Bidigare, R.R., Riebesell, U., Burkhardt, S., Wakeham, S.G., 2001. Controls on the molecular distribution and carbon isotopic composition of alkenones in certain haptophyte algae. Geochemistry Geophysics Geosystems 2, $2000 \mathrm{GC} 000057$.

Laws, E.A., Popp, B.N., Cassar, N., Tanimoto, J., 2002. ${ }^{13} \mathrm{C}$ discrimination patterns in oceanic phytoplankton: likely influence of $\mathrm{CO}_{2}$ concentrating mechanisms, and implications for paleoreconstructions. Functional Plant Biology 29, 323-333.

Lee, R.B.Y., Mavridou, D.A.I., Papadakos, G., McClelland, H.L.O., Rickaby, R.E.M., 2016. The uronic acid content of coccolith-associated polysaccharides provides insight into coccolithogenesis and past climate. Nature Communications 7, DOI: 10.1038/ncomms 13144 .

Lewis, E., Wallace, D., 1998. Program developed for $\mathrm{CO}_{2}$ system calculations: Oak Ridge TN Oak Ridge National Laboratory Environmental Sciences Division, v. 4735 . 
Mackinder, L., Wheeler, G., Schroeder, D., von Dassow, P., Riebesell, U., Brownlee, C., 2011. Expression of biomineralization-related ion transport genes in Emiliania huxleyi. Environmental Microbiology 13, 3250-3265.

Macko, S.A., Helleur, R., Hartley, G., Jackman, P., 1990. Diagenesis of organic mattera study using stable isotopes of individual carbohydrates. Organic Geochemistry 16, 1129-1137.

Marchal, O., Cacho, I., Stocker, T.F., Grimalt, J.O., Calvo, E., Martrat, B., Shackleton, N., Vautravers, M., Cortijo, E., van Kreveld, S., Andersson, C., Koc, N., Chapman, M., Sbaffi, L., Duplessy, J.C., Sarnthein, M., Turon, J.L., Duprat, J., and Jansen, E., 2002. Apparent long-term cooling of the sea surface in the northeast Atlantic and Mediterranean during the Holocene. Quaternary Science Reviews 21, 455-483.

Marsh, M.E., Ridall, A.L., Azadi, P., Duke, P.J., 2002. Galacturonomannan and golgi-derived membrane linked to growth and shaping of biogenic calcite. Journal of Structural Biology 139, 39-45.

Marsh, M.E., 2003. Regulation of $\mathrm{CaCO}_{3}$ formation in coccolithophores. Comparative Biochemistry and Physiology Part B: Biochemistry and Molecular Biology 136, $743-754$.

McClelland, H.L.O., Hermoso, M., Bruggeman, J., Rickaby, R.E.M., 2015. Towards a unifying theory for carbon isotopic partitioning in coccolithophores: Implications for paleo-proxies. Goldschmidt Abstracts, 2069. 
McClelland, H.L.O, Barbarin, N., Beaufort, L., Hermoso, M., Ferretti, P., Greaves, M., Rickaby, RE.M., 2016. Calcification response of a key phytoplankton family to millennial-scale environmental change. Scientific Reports 6, 34263.

McClelland, H.L.O., Bruggeman, J., Hermoso, M., Rickaby, R.E.M., 2017. The origin of carbon isotope vital effects in coccolith calcite. Nature Communications 8, DOI: 10.1038/ncomms 14511 .

Mehrbach, C., Culberson, C.H., Hawley, J.E., Pytkowicz, R.M., 1973. Measurement of the apparent dissociation constants of carbonic acid in seawater at atmospheric pressure. Limnology and Oceanography 18, 897-907.

Monson, K.D., Hayes, J.M., 1982. Carbon isotopic fractionation in the biosynthesis of bacterial fatty acids - Ozonolysis of unsaturated fatty acids as a means of determining the intramolecular distribution of carbon isotopes. Geochimica et Cosmochimica Acta 46, 139-149.

Mook, W.G., Bommerson, J.C., Staverman, W.H., 1974. Carbon isotope fractionation between dissolyed bicarbonate and gaseous carbon dioxide. Earth and Planetary Science Letters 22, 169-176.

Müller, M.N., Beaufort, L., Bernard, O., Pedrotti, M.L., Talec, A., Sciandra, A., 2012. Influence of $\mathrm{CO}_{2}$ and nitrogen limitation on the coccolith volume of Emiliania huxleyi (Haptophyta). Biogeosciences 9, 4155-4167.

O’Dea, S.A., Gibbs, S.J., Bown, P.R., Young, J.R., Poulton, A.J., Newsam, C., Wilson, P.A., 2014. Coccolithophore calcification response to past ocean acidification and climate change. Nature Communications 5, DOI:10.1038/ncomms6363. 
Pagani, M., Zachos, J., Freeman, K.H., Bohaty, S., Tipple, B., 2005. Marked decline in atmospheric carbon dioxide concentrations during the Paleogene. Science 309, $600-603$.

Perrin, L. Probert, I., Langer, G., Aloisi, G., 2016. Growth of the coccolithophore Emiliania huxleyi in light- and nutrient-limited batch reactors: relevance for the BIOSOPE deep ecological niche of coccolithophores. Biogeosciences 13, 59836001.

Popp, B.N., Laws, E.A., Bidigare, R.R., Dore, J.E., Hanson, K.L., Wakeham, S.G., 1998a. Effect of phytoplankton cell geometry on carbon isotopic fractionation. Geochimica et Cosmochimica Acta 62, 69-77.

Popp, B.N., Kenig, F., Wakeham, S.G., Laws, E.A., Bidigare, R.R., 1998b. Does growth rate affect ketone unsaturation and intracellular carbon isotopic variability in Emiliania huxleyi? Paleoceanography 13, 35-41.

Rau, G.H., Takahashi, T., Des Marais, D.J., Repeta, D.J., Martin, J.H., 1992. The relationship between $\delta^{13} \mathrm{C}$ of organic matter and $\left[\mathrm{CO}_{2(\mathrm{aq})}\right]$ in ocean surface water: Data from a JGOFS site in the northeast Atlantic Ocean and a model. Geochimica et Cosmochimica Acta 56, 1413-1419.

Rickaby, R.E.M., Bard, E., Sonzogni, C., Rostek, F., Beaufort, L., Barker, S., Rees, G., Schrag, D.P., 2007. Coccolith chemistry reveals secular variations in the global ocean carbon cycle? Earth and Planetary Science Letters 253, 83-95.

Rickaby, R.E.M., Hermoso, M., Lee, R.B.Y., Rae, B.D., Heureux, A.M.C., Balestreri, C., Chakravarti, L., Schroeder, D.C., Brownlee, C., 2016. Environmental carbonate 
chemistry selects for phenotype of recently isolated strains of Emiliania huxleyi. Deep-Sea Research II 127, 28-40.

Riebesell, U., Revill, A.T., Holdsworth, D.G., Volkman, J.K., 2000. The effects of varying $\mathrm{CO}_{2}$ concentration on lipid composition and carbon isotope fractionation in Emiliania huxleyi. Geochimica et Cosmochimica Acta 64, 4179-4192.

Romanek, C.S., Grossman, E.L., Morse, J.W., 1992. Carbon isotopic fractionation in synthetic aragonite and calcite: Effects of temperature and precipitation rate. Geochimica et Cosmochimica Acta 56, 419-430.

Rost, B., Zondervan, I., Riebesell, U., 2002. Light-dependent carbon isotope fractionation in the coccolithophorid Emiliania huxleyi. Limnology and Oceanography 47, $120-128$.

Rost, B., Riebesell, U., Sültemeyer, D., 2006. Carbon acquisition of marine phytoplankton: Effect of photoperiod length. Limnology and Oceanography 51, $12-20$.

Sakata, S., Hayes, J.M., McTaggart, A.R., Evans, R.A., Leckrone, K.J., Togasaki, R.K., 1997. Carbon isotopic fractionation associated with lipid biosynthesis by a cyanobacterium: Relevance for interpretation of biomarker records. Geochimica et Cosmochimica Acta 61, 5379-5389.

Schouten, S., Klein Breteler, W.C.M., Blokker, P., Schogt, N., Rijpstra, I.C., Grice, K., Baas, M., Sinninghe Damsté, J.S., 1998. Biosynthetic effects on the stable carbon isotopic compositions of algal lipids: Implications for deciphering the carbon isotopic biomarker record. Geochimica et Cosmochimica Acta 62, 1397-1406. 
Seki, O., Foster, G.L., Schmidt, D.N., Mackensen, A., Kawamura, K., Pancost, R.D., 2010. Alkenone and boron based Pliocene $p \mathrm{CO}_{2}$ records. Earth and Planetary Science Letters 292, 201-211.

Stoll, H.M., 2005. Limited range of interspecific vital effects in coccolith stable isotopic records during the Paleocene-Eocene thermal maximum. Paleoceanography 20, DOI: $10.1029 / 2004 P A 001046$.

Strickland, J.D.H., Parsons, T.R., 1968. Determination of reactive phosphorus. In: A Practical Handbook of Seawater Analysis. Fisheries Research Board of Canada, Bulletin 167, pp. 49-56.

Tang, T., Mohr, W., Sattin, S.R., Rogers, D.R., Girguis, P.R., Pearson, A., 2017. Geochemically distinct carbon isotope distributions in Allochromatium vinosum DSM 180T grown photoautotrophically and photoheterotrophically. Geobiology $15,324-339$.

Taylor, A.R., Brownlee, C., Wheeler G., 2017. Coccolithophore cell biology: chalking up progress. Annual Review of Marine Science 9, 283-310.

Tchernov, D., Gruber, D.F., Irwin, A., 2014. Isotopic fractionation of carbon in the coccolithophorid Emiliania huxleyi. Marine Ecology Progress Series 508, 53-66.

Teece, M.A., Fogel, M.L., 2007. Stable carbon isotope biogeochemistry of monosaccharides in aquatic organisms and terrestrial plants. Organic Geochemistry 38, 458-473.

Thierstein, H.R., Geitzenauer, K.R., Molfino, B., Shackleton, N.J., 1977. Global synchroneity of late Quaternary coccolith datum levels validation by oxygen isotopes. Geology 5, 400-404. 
Tsuji, Y., Yamazaki, M., Suzuki, I., Shiraiwa, Y., 2015. Quantitative analysis of carbon flow into photosynthetic products functioning as carbon storage in the marine coccolithophore, Emiliania huxleyi. Marine Biotechnology 17, 428-440.

van der Meer, M.T.J., Schouten, S., van Dongen, B.E., Rijpstra, I.C., Fuchs, G., Sinninghe Damsté, J.S., de Leeuw, J.W., Ward, D.M., 2001. Biosynthetic controls on the ${ }^{13} \mathrm{C}$ contents of organic components in the photoautotrophic bacterium Chloroflexus aurantiacus. The Journal of Biological Chemistry 276, 1097110976.

van Dongen, B.E., Schouten, S., Sinninghe Damsté, J.S., 2002. Carbon isotope variability in monosaccharides and lipids of aquatic algae and terrestrial plants. Marine Ecology Progress Series 232, 83-92.

Van Heuven, S., Pierrot, D., Rae, J.W.B., Lewis, E., Wallace, D.W.R., 2011. MATLAB program developed for $\mathrm{CO}_{2}$ system calculations. Carbon Dioxide Information Analysis Center, Oak Ridge National Laboratory.

Volkman, J.K., Eglinton, G., Corner, E.D.S., Sargent, J.R., 1980. Novel unsaturated straight-chain $\mathrm{C}_{37}-\mathrm{C}_{39}$ methyl and ethyl ketones in marine sediments and a coccolithophore Emiliania huxleyi. Physics and Chemistry of the Earth 12, 219227.

Westbroek, P., Brown C.W., van Bleijswijk, J., Brownlee, C., Brummer, G.J., Conte, M., Egge, J., Fernandéz, E., Jordan, R., Knappertsbusch, M., Stefels, J., Veldhuis, M., van der Wal, P., Young, J., 1993. A model system approach to biological climate forcing - the example of Emiliania huxleyi. Global Planetary Change 8, 27-46. 
Wilkes, E.B., Carter, S.J., Pearson, A., 2017. $\mathrm{CO}_{2}$-dependent carbon isotope fractionation in the dinoflagellate Alexandrium tamarense. Geochimica et Cosmochimica Acta $212,48-61$.

Wong, W., Sackett, W.M., Benedict, C.R., 1975. Isotope fractionation in photosynthetic bacteria during carbon dioxide assimilation. Plant Physiology 55, 475-479.

Young, J.R., Henricksen, K., 2003. Biomineralization vesicles: the calcite of coccoliths. Reviews in Mineralogy and Geochemistry 54, 189-214.

Zeebe, R.E., Wolf-Gladrow, D., 2001. $\mathrm{CO}_{2}$ in Seawater: Equilibrium, Kinetics, Isotopes. Elsevier, Amsterdam.

Zhang, J., Quay, P.D., Wilbur, D.O., 1995. Carbon isotope fractionation during gas-water exchange and dissolution of $\mathrm{CO}_{2}$. Geochimica et Cosmochimica Acta 59, 107114.

Zhang, J.-Z., Fischer, C.J., 2006. A simplified resorcinol method for direct spectrophotometric determination of nitrate in seawater. Marine Chemistry 99, $220-226$.

Zhang, Y.G., Pagani, M., Liu, Z., Bohaty, S.M., Deconto, R., 2013. A 40-million-year history of atmospheric $\mathrm{CO}_{2}$. Philosophical Transactions of the Royal Society A $371,20130096$.

Ziveri, P., Stoll, H., Probert, I., Klaas, C., Geisen, M., Ganssen, G.M., Young, J., 2003. Stable isotope 'vital effects' in coccolith calcite. Earth and Planetary Science Letters 210, 137-149.

Tables \& Figures 
Table 1. Experimental conditions and isotopic data for E. huxleyi $i^{\text {a,b }}$

\begin{tabular}{|c|c|c|c|c|c|c|}
\hline Expt \# & $\begin{array}{l}{\left[\mathrm{CO}_{2(\mathrm{aq})}\right]} \\
(\mu \mathrm{mol} / \mathrm{kg})\end{array}$ & $\begin{array}{l}\mu^{\mathrm{c}} \\
(/ \mathrm{d})\end{array}$ & $\begin{array}{l}\delta^{13} \mathrm{C}_{\text {calcite }} \\
(\%)\end{array}$ & $\delta^{13} \mathrm{C}_{\text {biomass }}(\% \mathrm{o})$ & $\delta^{13} \mathrm{C}_{\mathrm{CAP}}(\%)$ & $\delta^{13} \mathrm{C}_{\text {alkenone }}(\%)$ \\
\hline 1 & $17.6 \pm 1.2$ & $0.20 \pm 0.01$ & $-15.44 \pm 0.01(1)$ & $-48.2 \pm 1.4(9)$ & $-38.2 \pm 0.2(2)$ & $-51.5 \pm 1.0(7)$ \\
\hline 2 & $14.0 \pm 0.4$ & $0.40 \pm 0.01$ & $-12.90 \pm 0.01$ & $-45.7 \pm 0.1(5)$ & $-37.3 \pm 0.5(2)$ & $-49.8 \pm 0.9(2)$ \\
\hline 3 & $11.9 \pm 0.5$ & $0.48 \pm 0.01$ & $-10.44 \pm 0.01$ & $-42.9 \pm 0.3(4)$ & $-35.4 \pm 0.5(3)$ & $-46.4 \pm 0.5(7)$ \\
\hline 4 & $10.7 \pm 0.6$ & $0.62 \pm 0.01$ & $-8.26 \pm 0.01$ & $-39.5 \pm 0.9(7)$ & $-34.9 \pm 0.5$ & $-42.4 \pm 0.5(4)$ \\
\hline
\end{tabular}

${ }^{a}$ Values reflect the mean of steady state conditions, $\pm 1 \sigma$. The number of replicate isotopic measurements is listed in parentheses.

Sampling of cells for isotopic analysis was not begun until at least four doublings were completed at a given dilution rate.

${ }^{\mathrm{b}}$ The order in which the experiments were performed is: $2,3,1,4$.

${ }^{c}$ Values and associated errors correspond to the dilution rates applied to the chemostat system, equaling $\mu$ at steady state. 
Table 2. Isotopic offsets between cellular pools (\%o). ${ }^{\mathrm{a}}$

\begin{tabular}{llllll}
\hline Expt \# & $\Delta \delta^{13} \mathrm{C}_{\text {calcite-CAP }}$ & $\Delta \delta^{13} \mathrm{C}_{\text {CAP-biomass }}$ & $\Delta \delta^{13} \mathrm{C}_{\text {biomass-alkenone }}$ & $\Delta \delta^{13} \mathrm{C}_{\text {calcite-biomass }}$ & $\Delta \delta^{13} \mathrm{C}_{\text {alkenone-CAP }}$ \\
\hline \hline 1 & $22.7 \pm 0.2$ & $10.1 \pm 1.4$ & $3.3 \pm 1.7$ & $32.8 \pm 1.4$ & $-13.4 \pm 1.0$
\end{tabular}




$\begin{array}{llllll}2 & 24.4 \pm 0.5 & 8.4 \pm 0.5 & 4.2 \pm 0.9 & 32.8 \pm 0.1 & -12.6 \pm 1.1 \\ 3 & 24.9 \pm 0.5 & 7.5 \pm 0.6 & 3.5 \pm 0.6 & 32.5 \pm 0.3 & -11.0 \pm 0.7 \\ 4 & 26.7 \pm 0.5 & 4.5 \pm 1.0 & 2.9 \pm 1.0 & 31.2 \pm 0.9 & -7.4 \pm 0.7 \\ \text { Mean } & 24.7 & 8 & 3.5 & 32.3 & -11.1 \\ \text { SD } & 1.6 & 2 & 0.5 & 0.7 & 2.6\end{array}$

${ }^{\mathrm{a}}$ Values are $\pm 1 \sigma$ propagated error. 


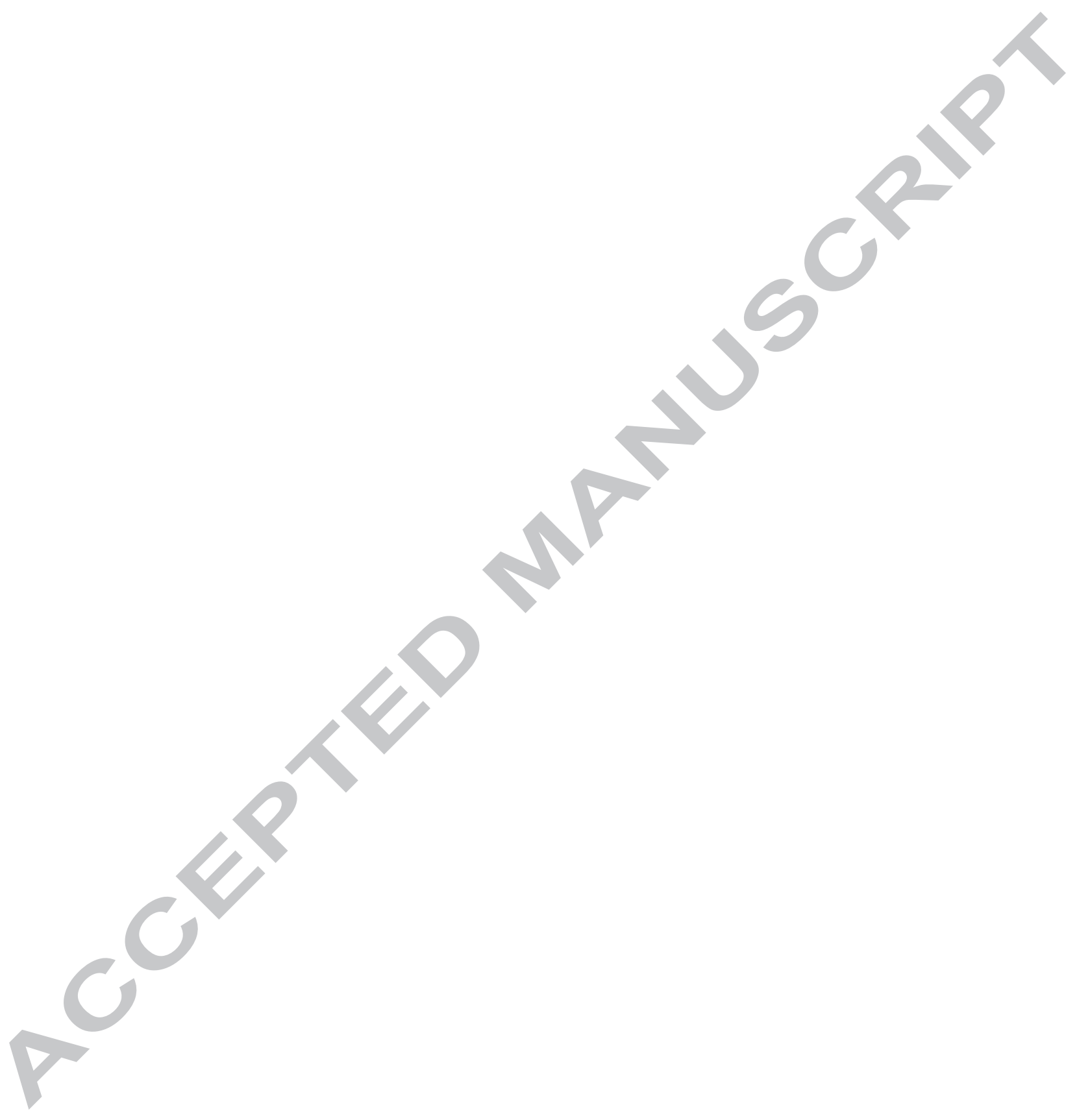




\section{ACCEPTED MANUSCRIPT}

Table 3. Four carbon allocation scenarios consistent with $\delta_{\text {biomass }}$ and $\delta_{\mathrm{CAP}}$ measurements.

\begin{tabular}{|c|c|c|c|c|c|c|c|c|c|c|c|c|c|c|}
\hline Relative $\delta$ & & Expt \# & $\delta_{\text {biomass }}$ & $f_{\text {lip }}$ & $\delta_{\text {lip }}$ & $f_{\text {prot }}$ & $\delta_{\text {prot }}$ & $f_{\text {carb }}$ & $\delta_{\text {carb }}$ & $f_{\mathrm{CAP}}$ & $\delta_{\mathrm{CAP}}$ & $f_{\text {sacc }}$ & $\delta_{\text {sacc }}$ & $\begin{array}{l}\text { \% carbon } \\
\text { allocation }\end{array}$ \\
\hline $\operatorname{Prot}^{a}$ & 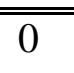 & 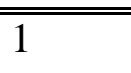 & -48.2 & "0.25 & -52.2 & "0.50 & -48.2 & 0.25 & -44.2 & 0.14 & -38.2 & 0.86 & -45.2 & 3.5 \\
\hline $\mathrm{Carb}^{\mathrm{a}}$ & 4 & 2 & -45.7 & 0.25 & -49.7 & 0.50 & -45.7 & 0.25 & -41.7 & 0.37 & -37.3 & 0.63 & -44.3 & 9.3 \\
\hline $\operatorname{Lip}^{\mathrm{a}}$ & -4 & 3 & -42.9 & 0.25 & -46.9 & 0.50 & -42.9 & 0.25 & -38.9 & 0.50 & -35.4 & 0.50 & -42.4 & 12.5 \\
\hline$\Delta \delta_{\text {CAP-sacc }}{ }^{\mathrm{a}}$ & 7 & 4 & -39.5 & 0.25 & -43.5 & 0.50 & -39.5 & 0.25 & -35.5 & 0.91 & -34.9 & 0.09 & -41.9 & 22.8 \\
\hline Prot & 1 & 1 & -48.2 & 0.25 & -52.2 & 0.63 & -47.2 & 0.13 & -45.2 & 0.13 & -38.2 & 0.87 & -46.2 & 1.6 \\
\hline Carb & 3 & 2 & -45.7 & 0.25 & -49.7 & 0.63 & -44.7 & 0.13 & -42.7 & 0.33 & -37.3 & 0.67 & -45.3 & 4.1 \\
\hline Lip & -4 & 3 & -42.9 & 0.25 & -46.9 & 0.63 & -41.9 & 0.13 & -39.9 & 0.44 & -35.4 & 0.56 & -43.4 & 5.5 \\
\hline$\Delta \delta_{\text {CAP-sacc }}$ & 8 & 4 & -39.5 & 0.25 & -43.5 & 0.63 & -38.5 & 0.13 & -36.5 & 0.80 & -34.9 & 0.20 & -42.9 & 10.0 \\
\hline Prot & 0 & 1 & -48.2 & 0.25 & -52.2 & 0.42 & -48.2 & 0.33 & -45.2 & 0.13 & -38.2 & 0.87 & -46.2 & 4.3 \\
\hline Carb & 3 & 2 & -45.7 & 0.25 & 497 & 0.42 & -45.7 & 0.33 & -42.7 & 0.33 & -37.3 & 0.67 & -45.3 & 10.9 \\
\hline Lip & -4 & 3 & -42.9 & 0.25 & -46.9 & 0.42 & -42.9 & 0.33 & -39.9 & 0.44 & -35.4 & 0.56 & -43.4 & 14.5 \\
\hline$\Delta \delta_{\mathrm{CAP}-\mathrm{sacc}}$ & 8 & 4 & -39.5 & 0.25 & -43.5 & 0.42 & -39.5 & 0.33 & -36.5 & 0.80 & -34.9 & 0.20 & -42.9 & 26.4 \\
\hline
\end{tabular}




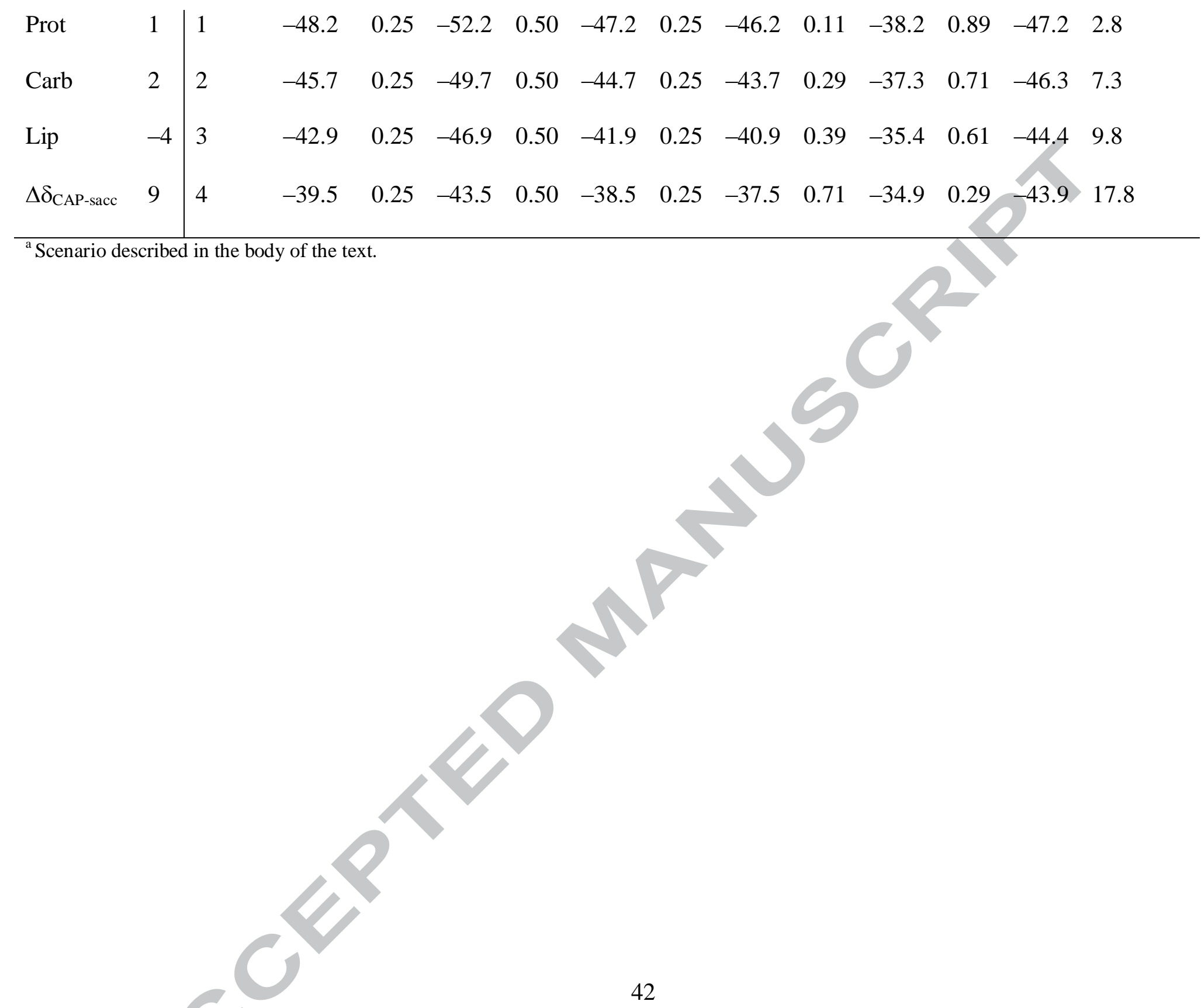




\section{Figure Captions}

Fig. 1. The $\delta^{13} \mathrm{C}$ values (\%o) of coccolith calcite (black triangles), CAPs (grey circles), bulk biomass (white squares), and alkenones (black diamonds) (a) as a function of the ratio of growth

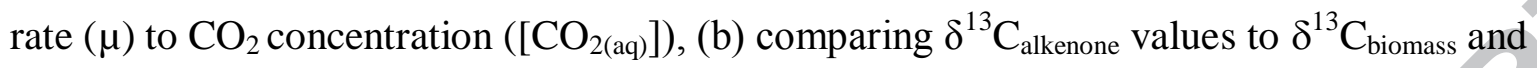
$\delta^{13} \mathrm{C}_{\text {calcite }}$ values, with slopes of approximately 1 , and (c) comparing $\delta^{13} \mathrm{C}_{\mathrm{CAP}}$ values to $\delta^{13} \mathrm{C}_{\text {biomass }}$ and $\delta^{13} \mathrm{C}_{\text {calcite, }}$, showing slopes of approximately 0.5 .

Fig. 2. Isotopic fractionations ( $\Delta \delta$ values, \%o) between compound classes, calculated as simple

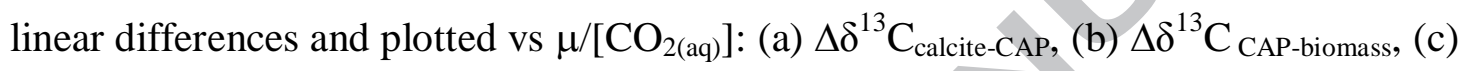
$\Delta \delta^{13} \mathrm{C}_{\text {biomass-alkenone, }}$ (d) $\Delta \delta^{13} \mathrm{C}_{\text {calcite-biomass. Error bars represent }} \pm 1 \sigma$ propagated error. Note: all vertical axes span $12 \%$ ranges, but with different values.

Fig. 3. Predicted cellular carbon allocation to major organic compound classes in E. huxleyi. Arrow widths correspond to calculated fractional fluxes $(f)$. Relative shading intensities indicate the measured or predicted isotopic offsets between the organic carbon pools, including the bulk biomass. (a) Cells from Experiment \#1 (left; lowest $\mu /\left[\mathrm{CO}_{2(\mathrm{aq})}\right]$ ) preferentially allocate carbon within the carbohydrate pool to saccharides other than CAPs. Cells from Experiment \#4 (right; highest $\left.\mu /\left[\mathrm{CO}_{2(\mathrm{aq})}\right]\right)$ allocate more carbon to CAP synthesis. (b) Percentages of fixed carbon allocated to CAPs for each experiment, calculated for four plausible combinations of $\delta_{\text {prot }}$ and $\delta_{\text {carb }}$ model inputs. Regardless of choice, carbon allocation to CAPs is expected to increase from Experiment \#1 to Experiment \#4 (with increasing $\left.\mu /\left[\mathrm{CO}_{2(\mathrm{aq})}\right]\right)$. Abbreviations: $P D H=$ pyruvate dehydrogenase, $\mathrm{OAA}=$ oxaloacetate. 
Fig. 1.
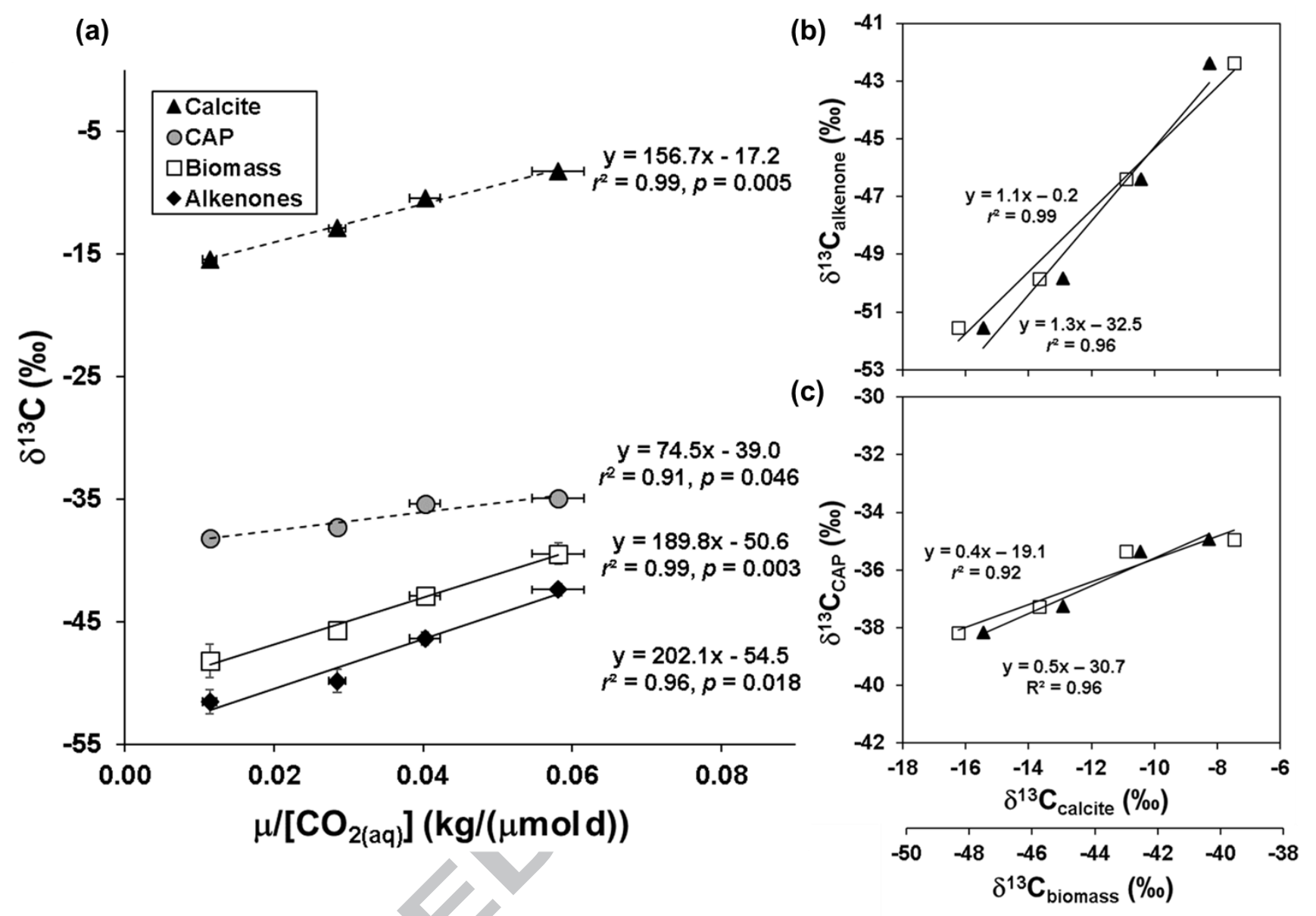
Fig. 2.
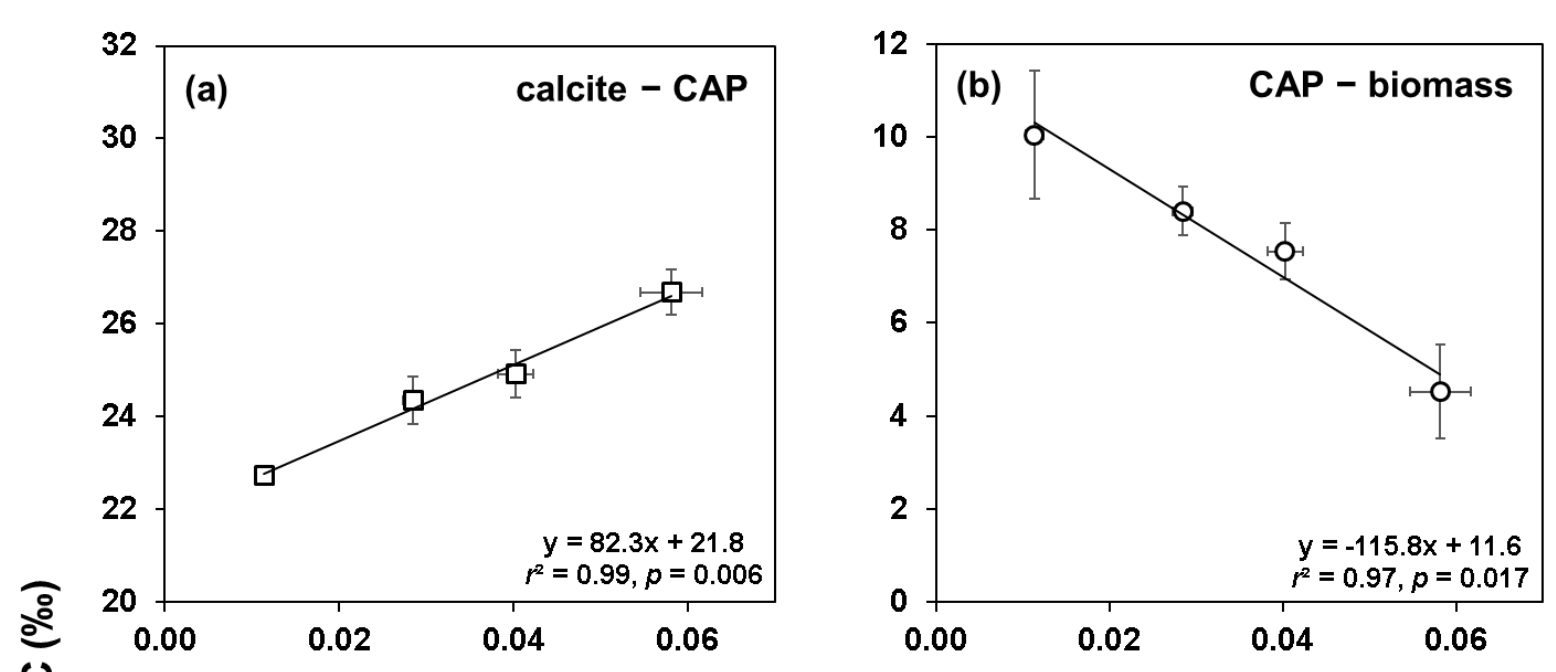

$\frac{0}{10}$
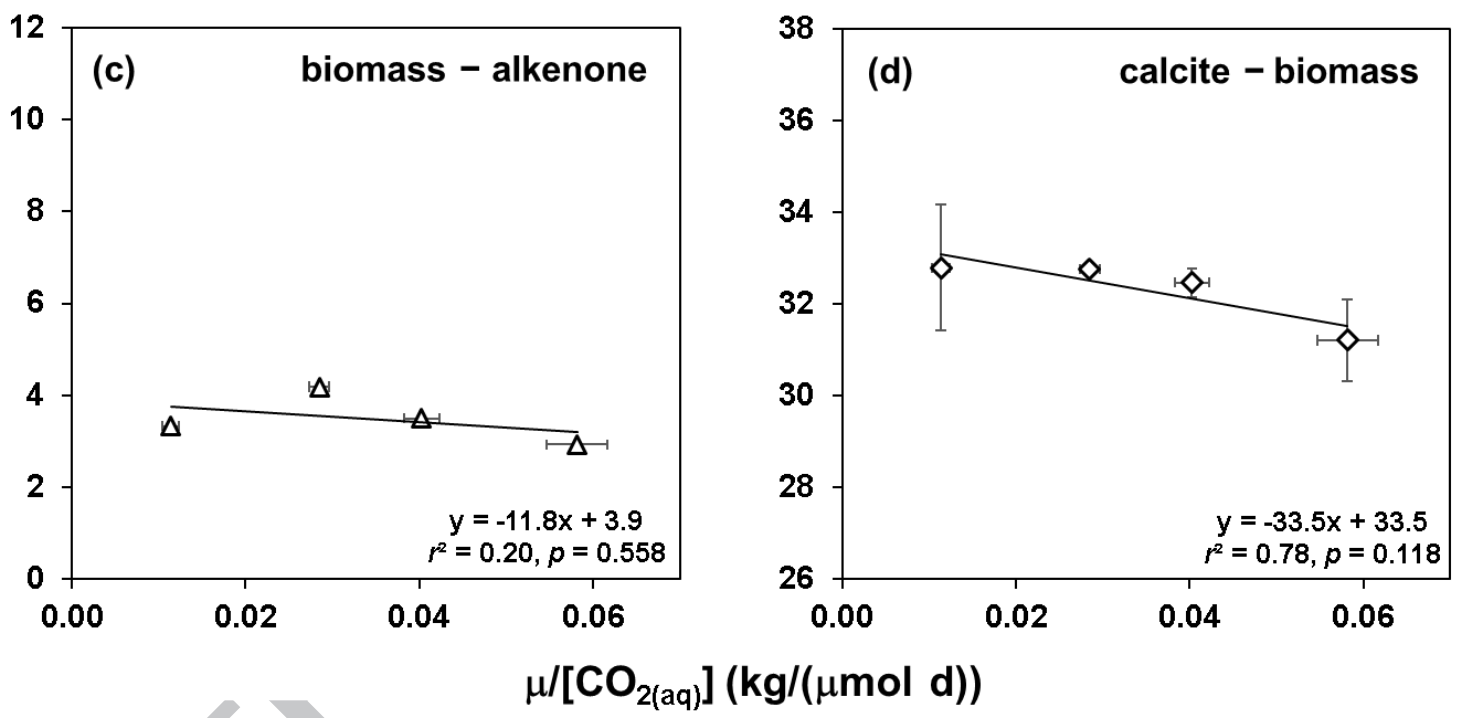
Fig. 3.
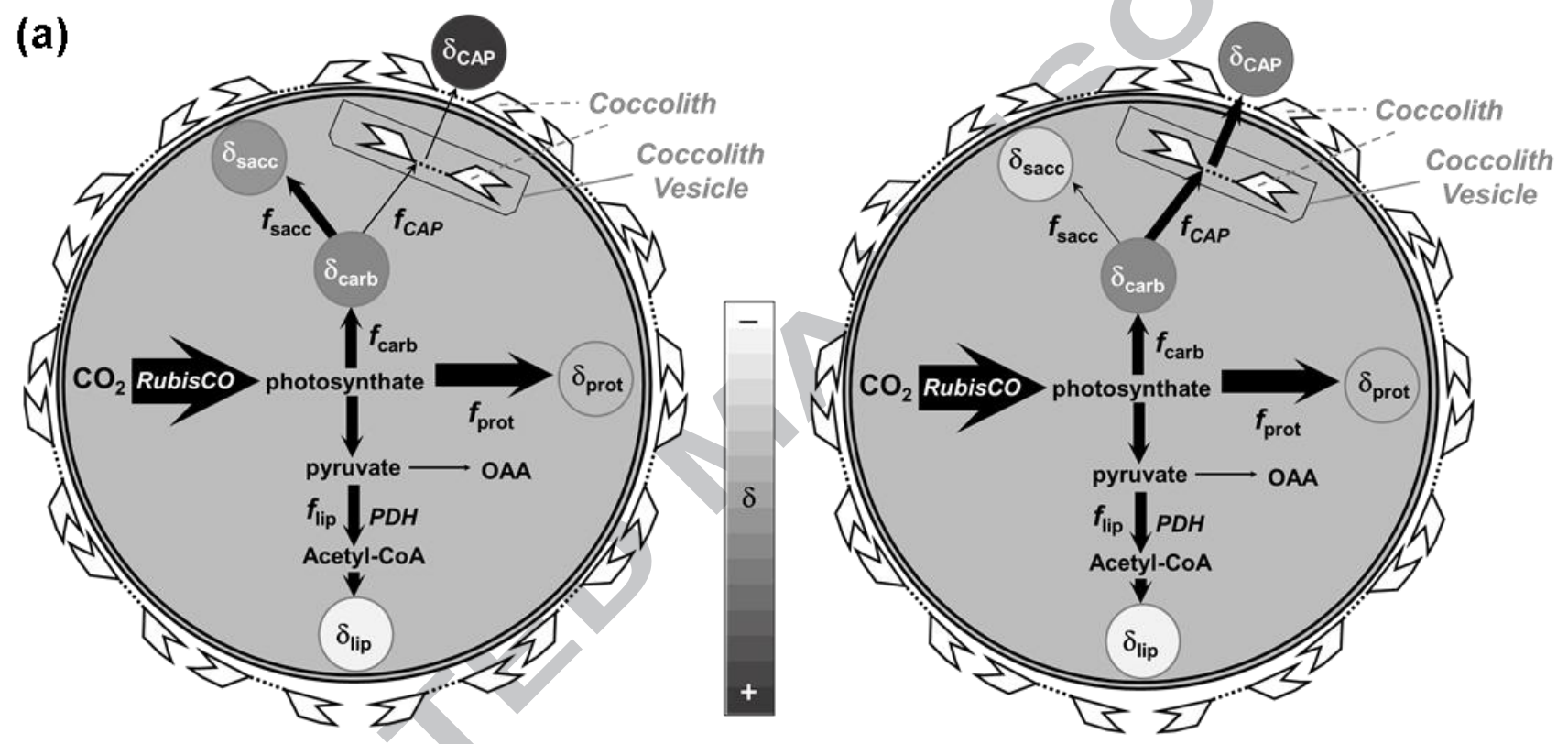

(b)

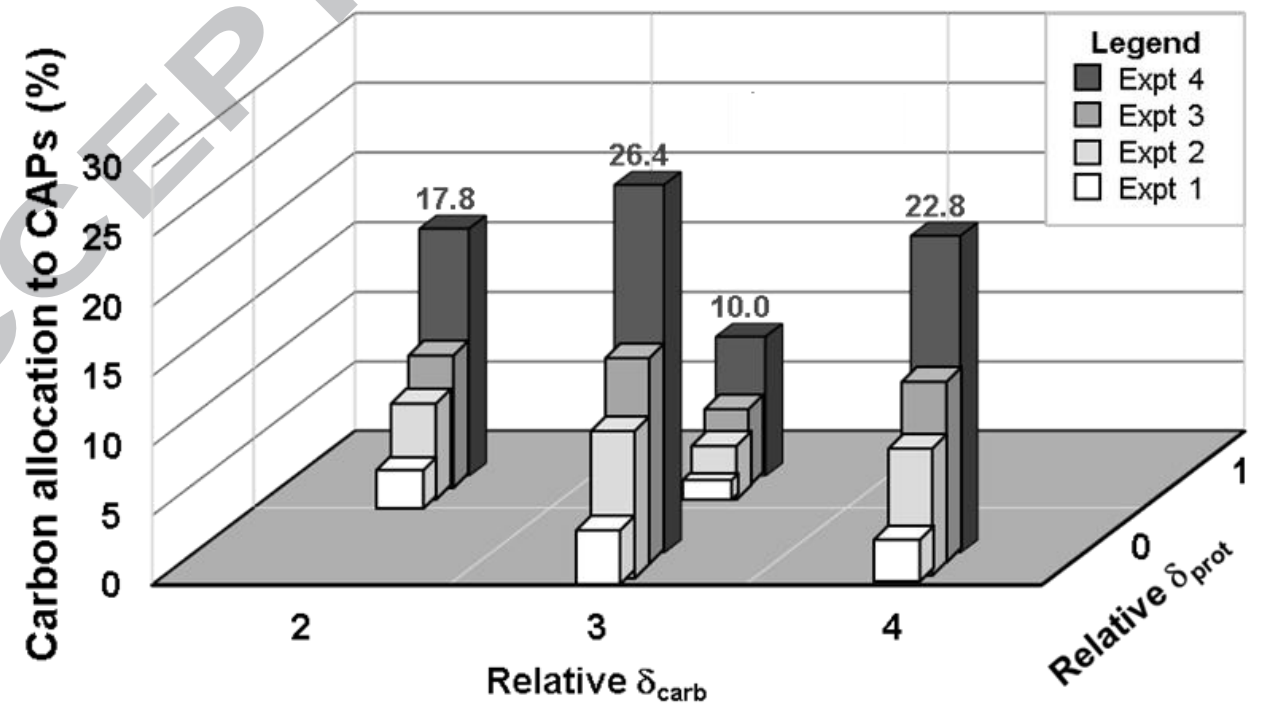




\section{Highlights}

- $\delta^{13} \mathrm{C}$ values of coccolith polysaccharides (CAPs) vary with growth rate and $\mathrm{CO}_{2}$

- CAPs from E. huxleyi are ${ }^{13} \mathrm{C}$-enriched compared to bulk biomass by 4.5 to $10.1 \%$

- $\mathrm{CAP} \delta^{13} \mathrm{C}$ values are less sensitive to growth rate/ $\mathrm{CO}_{2}$ than alkenones

- They are also less sensitive than biomass or coccolith calcite

- $\delta^{13} \mathrm{C}$ values of alkenones, calcite, and CAPs may together reconstruct paleo- $p \mathrm{CO}_{2}$ 